Article

\title{
Foreign Aid and Climate Change Policy: What Can('t) the Data Tell Us?
}

\author{
Daniel Yuichi Kono * and Gabriella R. Montinola \\ Department of Political Science, University of California — Davis, CA 95616, USA; E-Mails: dykono@ucdavis.edu (D.Y.K.), \\ grmontinola@ucdavis.edu (G.R.M.)
}

* Corresponding author

Submitted 22 November 2018 | Accepted: 14 January 2019 | Published: 5 June 2019

\begin{abstract}
Climate-related foreign aid is on the rise, with signatories to the Paris Climate agreement pledging $\$ 100$ billion annually to promote mitigation and adaptation in recipient countries. While this seems like a welcome development, we have little evidence that climate aid actually encourages recipients to adopt climate legislation. In this article, we examine the relationship between climate aid and recipient climate policy. Using multiple measures of each, we find no evidence that the former is systematically related to the latter. Although this suggests that climate aid is ineffective, this conclusion must be qualified due to the poor quality of both climate aid and climate policy data. More definitive conclusions will require more accurate coding of climate aid as well as better climate policy measures that distinguish truly consequential policies from less consequential ones.
\end{abstract}

\section{Keywords}

adaptation; climate change; climate policy; environmental policy; foreign aid; mitigation

\section{Issue}

This article is part of the issue "Aid Impact and Effectiveness", edited by Rachel M. Gisselquist and Finn Tarp (UNU-WIDER, Finland).

(C) 2019 by UNU-WIDER; licensee Cogitatio (Lisbon, Portugal). This article is licensed under a Creative Commons Attribution 4.0 International License (CC BY).

\section{Introduction}

Concerns about climate change continue to mount, along with scientific evidence of its risks. A recent report by the United Nations Intergovernmental Panel on Climate Change concluded that a "business as usual" scenario would lead global temperatures to rise by 1.5 degrees Celsius above pre-industrial levels by 2040 (Masson-Delmotte \& et al., 2018). The likely consequences include rising sea levels, worsening droughts and wildfires, food shortages, species extinctions and extreme weather events. Preventing these changes will be difficult, requiring the virtual elimination of carbon emissions over the next two decades. This presents particular challenges for developing countries, which will need to undertake costly mitigation measures even as they struggle to adapt to these climatic effects. ${ }^{1}$
One way to help poor countries respond to the climate challenge is to increase climate-related foreign aid. Aid could reduce the economic costs of mitigation measures, help developing countries adapt to climaterelated threats, and incentivize recipients to adopt such policies. For these reasons, aid has become a central plank in efforts to combat climate change. During the 2009 Copenhagen climate conference, developed countries pledged $\$ 100$ billion annually to assist developing countries with mitigation and adaptation, and this commitment was formalized in Article 9 of the Paris Climate Agreement (United Nations Framework Convention on Climate Change [UNFCCC], 2015). The rising prominence of climate aid raises a perennial question: Is foreign aid effective? Does it really help recipients combat climate change?

This question is important, given the mixed overall track record of foreign aid. As Qian (2015, p. 280) notes,

\footnotetext{
${ }^{1}$ This is not to suggest that developing countries are primarily responsible for solving the climate problem: only a few are major emitters, and developed countries account for the bulk of historical carbon emissions. Our point is that the costs of mitigation and adaptation are particularly burdensome to countries that are already poor.
} 
research on the effects of aid has yielded no firm conclusions: "Depending on the measures used, the empirical strategy employed, and the context of the study, the results can vary widely, from finding that aid can be quite beneficial to being harmful." Moreover, this research focuses mostly on economic growth and development: we have no systematic evidence on whether aid influences recipient environmental policy. Case studies suggest that appropriately designed aid programs can facilitate climate policy adoption (Barnett, 2008; Chen \& He, 2013). However, the broader literature on aid makes clear that potential benefits are not always realized. We thus need more systematic research on how climate aid affects recipient climate policies.

Such research requires good data on both variables. Unfortunately, we lack such data. Although the OECD Development Assistance Committee (DAC)'s "Rio markers" are meant to identify climate-related aid, a number of studies demonstrate that these markers lack both validity and reliability (Donner, Kandlikar, \& Webber, 2016; Hicks, Parks, Roberts, \& Tierney, 2008; Junghans \& Harmeling, 2012; Michaelowa \& Michaelowa, 2011; Roberts \& Weikmans, 2017; Weikmans, Roberts, Baum, Bustos, \& Durand, 2017). Extant measures of climate policy exhibit even more serious problems. The mere ratification of international climate agreements such as the Kyoto Protocol or the UNFCCC tells us little about how seriously signatories are addressing climate change through domestic policies. The Grantham Institute's Climate Change Laws of the World database (n.d.) provides a wealth of information on national climaterelated laws. But without coding this legislation for scope, depth and implementation, we cannot aggregate these laws into a meaningful measure of climate action. Of extant measures, Steves and Teytelboym's (2013) Climate Laws, Institutions and Measures Index (CLIMI) comes closest to accurately measuring national climate policy. But as we discuss below, this measure also has serious limitations.

Although these data limitations are well-known, they require emphasis because, in the absence of good alternatives, scholars increasingly employ these data to draw conclusions about both climate aid and climate policy. For example, Bagchi, Castro and Michaelowa (2016), Betzold and Weiler (2017), Halimanjaya and Papyrakis (2015), Klöck, Molenaers and Weiler (2018), and Weiler, Klöck and Dornan (2018) all employ Rio markers to study the allocation of climate aid, while Schmidt and Fleig (2018) employ counts of Grantham climate laws to study the evolution of national climate policies. Without addressing the abovementioned measurement concerns, such studies may provide a misleading picture of developments in both policy domains.

To illustrate this point, we examine the relationship between extant measures of climate aid and climate pol- icy. We obtain climate aid data from Tierney et al. (2011), which includes the Rio markers, and Michaelowa and Michaelowa (2011), who provide an alternative and arguably more accurate coding of mitigation and adaptation aid. We employ climate policy data from the Grantham Institute and Steves and Teytelboym (2013). Given the questionable validity of both aid and climate policy measures, we do not expect to find any associations between the two beyond what might result from random measurement error. This is exactly what we find. Of 66 estimated aid coefficients, only three (4.5 percent) are significant-which, at the .05 significance level, is about what random measurement error would produce. These null results are robust to various measures, samples and estimation techniques. Moreover, even the three significant coefficients are anomalous: for example, mitigation aid predicts adaptation policies but not mitigation policies. There seems little reason to attribute these results to anything but random chance.

Of course, we do not know that our null results reflect measurement error. It is also possible that climate aid really does not affect recipient climate policies, or that endogenous aid allocation - which we have been unable to adequately address - biases our analyses toward null results. Without knowing the true relationship between climate aid and climate policy-which we cannot know without better data-we cannot reject these alternative interpretations. It is worth noting, however, that our control variables also fare poorly: only a handful of coefficients are significant, none of them robustly across the various models. This also suggests that we are trying to predict variation that is more random than systematic. ${ }^{2}$ Given the known limitations of extant climate aid and policy measures, the simplest explanation for our results is "garbage in, garbage out." That is, we cannot expect to find robust, significant relationships among variables that are largely unrelated to the concepts of interest.

For this reason, we do not conclude that climate aid is ineffective at combating climate change. Rather, our central message is that we cannot even begin to study this question without a much larger investment in measurement techniques and data collection. With foreign aid, the central challenge is identifying aid that is clearly climate-relevant. Previous studies provide some guidelines for doing so (Donner et al., 2016; Junghans \& Harmeling, 2012; Michaelowa \& Michaelowa, 2011; Roberts \& Weikmans, 2017; Weikmans et al., 2017), but implementation remains a formidable task. With climate policy, the task is more difficult still. Diverse national policies-carbon taxes, cap-and-trade systems, clean energy subsidies, regulatory requirements, petrol taxes, feed-in tariffs, energy efficiency measures, and so on-must somehow be aggregated into a single crossnationally comparable metric, ideally after weighting these policies according to not only their importance on

\footnotetext{
2 Steves and Teytelboym (2013) are more successful at predicting variation in the CLIMI index. This is probably because their sample includes developed countries, which we do not include due to our focus on aid recipients. Our different results suggest that CLIMI is better at measuring variation between developed and developing countries than within the latter group alone.
} 
paper but also their implementation. Although this is a daunting task, it is similar to that faced by trade-policy scholars who must aggregate diverse nontariff barriers into a single ad valorem tariff equivalent (Kee, Nicita, \& Olarreaga, 2009). Their success at doing so suggests that climate scholars may also find ways to construct, for example, an ad valorem carbon tax equivalent. In any case, progress toward this goal is essential if we are to say with any confidence whether and how foreign aid affects climate policy.

\section{Climate Aid and Climate Policy}

For concreteness, we begin by clarifying the scope of our study. First, we are interested in the effects of climate aid, i.e., aid meant to promote either climate change mitigation or adaptation. Such aid has risen dramatically in recent years. In 2001, donors established several funds to increase poor-country participation in the Kyoto Protocol: an adaptation fund, a fund to finance the transition to greener technologies, and a Clean Development Mechanism to finance greenhouse-gas reducing projects (Hicks et al., 2008, pp. 258-259). At the 2009 Copenhagen conference, donors pledged $\$ 100$ billion annually to promote mitigation and adaptation, and this commitment was formalized in the Paris Climate Agreement. Although disbursements have lagged behind these commitments, there seems little doubt that climate aid is on the rise. According to the OECD (n.d.), total climate-related aid rose from around $\$ 700$ million in 2000 to $\$ 19$ billion in 2010 to $\$ 52$ billion in 2016 .

Second, we focus on bilateral rather than multilateral aid. This is partly because we rely on Michaelowa and Michaelowa's (2011) coding, which covers only bilateral aid. However, it is also true that most climate aid is bilateral. Victor $(2013$, p. 5) estimates that "bilateral climate change assistance is more than twenty times larger than multilateral funds," and Marcoux, Parks, Peratsakis, Roberts and Tierney (2013) show that this trend toward bilateralism is increasing over time. Bilateral aid is thus substantively more important and more likely to have discernible effects.

Third, we are interested in how this aid affects recipient climate policies: i.e., policies that either mitigate climate change (by reducing greenhouse gas emissions) or adapt to its effects (by taking measures to deal with rising sea levels, droughts, crop failures, etc.). Such policies have also proliferated in recent years. For example, in 2008, Brazil passed the "National Plan on Climate Change"; Chile passed the "National Climate Change Action Plan"; India passed the "National Action Plan on Climate Change," and so on (Grantham Institute, n.d.). Although some of these policies are of questionable significance, it is clear that a growing number of poor countries are making at least a cosmetic effort to address climate change.
This focus excludes some important questions. Our focus on climate aid means that we do not consider the effects of development aid more broadly. Similarly, our focus on climate policies means that we do not consider direct economic links between aid and climate change, e.g., aid-fueled growth causing higher carbon emissions. Although these issues are worth exploring, it is important to look specifically at the climate aid-policy link. Climate aid is donors' key policy lever for helping poor countries cope with climate change. If it does not work, we must ask whether these funds could be more effectively used in other ways. And while aid could affect climate outcomes through non-legislative channels, large-scale mitigation and adaptation seem unlikely without public policies that alter private-sector incentives.

How might climate aid affect recipient climate policies? Perhaps the simplest mechanism is that aid can relax the recipient government's budget constraint, allowing it to spend more on climate mitigation or adaptation. This is the intuition in Chao and Yu (1999) and Hatzipanayotou, Lahiri and Michael (2002): in these models, an increase in foreign aid reduces pollution by increasing resources for pollution abatement. The increased-spending link is clearly relevant to adaptation measures, which typically require governments to spend money on projects such as dikes, dams, wells, irrigation, and so on. However, fiscal resources can also play an important role in mitigation policy in the form of subsidies or tax breaks to encourage clean energy production and consumption. An important caveat to this argument, as Eyckmans, Fankhauser and Kverndokk (2016) note, is that climate aid may simply allow recipients to reallocate their current climate finance to other ends, yielding no net increase in climate-related spending. They recommend giving climate aid in the form of matching grants, in which aid is proportional to domestic climate spending. ${ }^{3}$

Even if aid incentivizes climate action via increased resources, we need to ask why it would lead to new climate legislation-an important question because our empirical analysis focuses on such legislation rather than spending per se. Much aid is project-specific: it is earmarked for projects such as dams, wind turbines, and rural infrastructure projects. Why would external funding for such projects lead recipients to pass new legislation?

One answer is that aid could boost the need for implementing legislation, i.e., laws that implement projects wholly or partially funded by aid. For example, Vietnam's “Decisions No. 37/2011/QD-TTg and 39/2018/QD-TTg on the support for Wind Power Projects" (Vietnam Law \& Legal Forum, 2011) provides detailed rules for the establishment and operation of wind power projects, including licensing requirements, electricity purchase prices per kilowatt-hour, subsidies per kilowatt-hour, and so on. Although aid probably did not "cause" this legislation, the latter would not exist without wind power projects.

\footnotetext{
${ }_{3}^{3}$ Matching grants would constitute a form of aid conditionality. This is another possible channel through which aid donors could influence recipient climate policy. At present, however, this possibility is largely hypothetical, since climate aid is generally not conditional.
} 
To the extent that aid makes such project possible, it also generates a need for the implementing legislation.

Perhaps more importantly, much climate aid funds "capacity building" projects. Capacity building is a broad concept that, in this context, largely boils down to a society's ability to formulate and implement mitigation and adaptation policies. As such, it encompasses such diverse elements as training public and private-sector actors, building bureaucracies to formulate and implement policies, and educating the public (Victor, 2013). Although capacity building involves both the public and private sector, the government plays a central role. It is typically government agencies that manage and coordinate activities like scientific research, planning and building infrastructure, taxing fossil fuels and subsidizing clean energy, disaster relief, and so on. For this reason, a large fraction of climate aid is targeted toward government capacity building (Victor, 2013, p. 4).

Building government capacity typically involves legislation. In fact, of the 1,512 climate laws currently listed in the Grantham database, 127 (8 percent) are wholly dedicated to building institutions and administrative arrangements, and another 700 (46 percent) are partially dedicated to this goal. An example is Mali's "Decree No. 2011-107-PM-RM of March 11, 2011 establishing the National Climate Change Committee of Mali" (Republic of Mali, 2011). This created a National Climate Change Committee responsible for implementing UNFCCC and other international obligations, securing funding for this purpose, preparing Mali's participation in international climate conferences, and providing the government with information on climate-related issues. The linkages with aid are clear: this legislation was passed in part to help Mali administer aid-financed projects, as well as to secure future funding. More generally, if aid increases the fiscal feasibility of climate measures, it also creates a need for administrative institutions and personnel, and hence for capacity-building legislation.

Despite these plausible linkages, there are reasons to doubt the efficacy of climate aid. One is the mixed record of foreign aid more generally (Qian, 2015). If development aid often doesn't work-due to waste, corruption, bad governance, etc. - it is not clear why climate aid should fare any better. Studies on environmental aid specifically reinforce this point. For example, Connolly (1996, p. 333) notes that "donors do not always provide aid in order to solve environmental problems...donor governments...sometimes care more about the appearance of doing something...than about finding genuine solutions." Michaelowa and Michaelowa (2011) support this view, showing that (1) much climate aid has nothing to do with climate-related projects, and (2) governments have domestic political motives to attach climate markers to aid. If donors simply want to show that they are "doing something," they may not monitor recipients closely-and the latter may do little themselves. This un- derscores the need to examine the aid-climate policy link empirically.

Although there is a growing body of research on climate aid allocation (Bagchi et al., 2016; Betzold \& Weiler, 2017; Halimanjaya \& Papyrakis, 2015; Hicks et al., 2008; Klöck et al., 2018; Weiler et al., 2018), we know little about its effects. A study of World Bankfinanced projects found that the track record of environmental projects is poor: only 26 percent of environmental project outcomes were deemed satisfactory, compared with an average success rate of 80 percent in eight other sectors (World Bank, 2005, p. 12). We do not know how many of these projects were climate-related, however, or whether any of them involved policy changes. Case studies that focus on climate aid show that welldesigned programs can facilitate mitigation and adaptation (Barnett, 2008; Chen \& He, 2013). However, due to their narrow scope, these studies reveal more about what is possible than what is typical.

Mak Arvin, Dabir-Alai and Lew (2006) examine the relationship between development aid and carbon dioxide $\left(\mathrm{CO}_{2}\right)$ emissions. They find causality in both directions: aid causes emissions and emissions cause aid. However, the sign of this relationship (positive or negative) varies across countries, and "no obvious grouping of developing countries with common characteristics emerges with respect to a particular causal finding" (Mak Arvin et al., 2006, p. 76). Their results are thus mixed. Moreover, these emissions-based results probably reflect the association between $\mathrm{CO}_{2}$ emissions and growth: that is, aid causes higher (lower) emissions when it promotes (hinders) growth, and emissions cause increased (decreased) aid when donors reward recipients for good (bad) growth performance. Hence, while these results are interesting, they also tell us little about the aid-climate policy link. Given the dearth of direct evidence on this relationship, there is a pressing need for further empirical research.

\section{Data Sources}

We obtain data on climate aid and climate policy from well-established and widely used sources. Our aid data are from AidData's project-level database (Tierney et al., 2011), which provides data on aid commitments and disbursements from the OECD Creditor Reporting System as well as individual donor agencies (AidData, n.d.). ${ }^{4}$ Our climate policy data are from the Grantham Research Institute on Climate Change and the Environment and from Steves and Teytelboym (2013), which introduces the CLIMI index. Although these are, to our knowledge, the best available sources of data on climate aid and climate policy, they raise a number of measurement concerns. We discuss these concerns below, beginning with climate aid.

In 1995, donors began coding aid projects with "Rio markers," which indicate whether projects relate to bio-

\footnotetext{
${ }^{4}$ PLAID version 1.9.2 was accessed on 19 October 2010. We use this release of the data because it employs the same project codes as Michaelowa and Michaelowa (2011).
} 
diversity, desertification or climate change. In 2011, donors also began classifying climate aid according to its purpose (mitigation or adaptation). In principle, these markers make it easy to identify climate-related bilateral aid. In practice, scholars have questioned how accurately these markers convey the true purpose of aid.

Assessments of the original (pre-2011) Rio climate marker-which, strictly speaking, only pertained to mitigation projects-were skeptical. For example, Roberts, Starr, Jones and Abdel-Fattah (2008) examined a random sample of 115,000 aid projects and found that only 25 percent of projects with Rio climate markers were actually relevant to climate change. Michaelowa and Michaelowa (2011) examined all 636,962 aid activities in the DAC database and came to similar conclusions. Of the 10,414 projects with Rio markers, only 2,798 (27 percent) had any relevance to mitigation. Another 1,277 projects (12 percent) were relevant to adaptation. Even if we broaden the DAC's definition of climate relevance to include both mitigation and adaptation, nearly two-thirds of projects with Rio markers had nothing to do with climate. As examples of such miscoding, Michaelowa and Michaelowa (2011, p. 2010) cite the following (donors in parentheses):

- Savannah elephant vocalization (US);

- Uniforms for park guardians in Central America (Spain);

- Tobacco control (New Zealand);

- Lead reduction in transport fuels in Pakistan (UK);

- Earthquake safety (Switzerland);

- Monetary climate in Democratic Republic of Congo (Belgium);

- Love movie festival (Belgium).

Michaelowa and Michaelowa (2011) conclude that, while some errors are probably accidental, donors also have incentives to deliberately miscode data to give the appearance of addressing climate change.

Studies on the post-2010 Rio Markers, which code projects for both mitigation and adaptation, have been no less critical. Junghans and Harmeling (2012) conclude that 65 percent of projects with the adaptation marker are unrelated to adaptation. Moreover, the degree of over-reporting varies across donors: hence the Rio marker lacks reliability as well as validity. Weikmans et al. (2017, p. 458) reach similar conclusions, arguing that "the absence of independent quality control makes the adaptation Rio marker data almost entirely unreliable." These coding irregularities have made their way into real-world policy debates: for example, during the Paris climate negotiations, India argued that developed countries provided only $\$ 2.2$ billion of climate aid in 2014 , rather than the $\$ 62$ billion claimed by donors (Roberts \& Weikmans, 2017, p. 130). For our purposes, the central problem is that these inaccuracies make it difficult to credibly estimate the effects of climate aid.
Although we employ Rio markers in our analysis, we also use Michaelowa and Michaelowa's alternative (2011) coding. We do this for two reasons. First, because the latter data have been coded by disinterested third parties, they should be more accurate than donorreported data. Second, Michaelowa and Michaelowa's (2011) data allow us to distinguish mitigation and adaptation aid prior to 2011. For both reasons, these data should permit us to estimate more accurately the relationship between climate aid and climate policy.

If the climate aid data are questionable, climate policy data raise even greater measurement concerns. As Bernauer (2013, p. 435) observes, existing datasets "offer aggregate measures of ambition levels of climate policies but no information on the adoption of specific climate policy instruments." The measurement problem is twofold. First, it is difficult to assess the contribution each policy makes to climate mitigation or adaptation. How, for example, can we compare a national carbon tax, a cap-and-trade program, a set of subsidies for clean energy, and a law mandating energy efficiency? In principle, each policy could be converted into a comparable metric such as a carbon tax equivalent or an estimated emissions reduction. In practice, this econometric task has yet to be achieved, making it difficult to compare the depth and scope of diverse national policies. Second, without accomplishing this first task, we cannot aggregate diverse policies into a single national index of climate mitigation or adaptation. Some scholars circumvent these problems by treating international commitments-for example, ratification of the Kyoto Protocol or the UNFCCC-as proxies for climate orientation (Bättig \& Bernauer, 2009; Neumayer, 2002; von Stein, 2008). However, because these agreements impose no binding emissions commitments on most aid recipients, and because membership is now nearly universal, ratification alone tells us little about signatories' climate policies.

In the absence of better alternatives, some scholars have begun to analyze national climate policies using a simple count of climate-related laws. For example, Schmidt and Fleig (2018) document the evolution of national climate policies using the Grantham Institute's Climate Change Laws of the World database. This is a comprehensive catalog of climate-related laws passed in all countries of the world from 1963 to 2018. Besides providing verbal descriptions, it classifies each law by function: energy supply, energy demand, institutions/administrative arrangements, adaptation, REDD+ and LULUCF, research and development, transportation, and carbon pricing. The appeal of this dataset is clear: it provides an off-the-shelf source of data on various dimensions of climate policy. However, while the Grantham database is an invaluable resource, it does not yet provide enough information to compare the various laws or to aggregate them into a single climate policy index. 
To begin with the first point: Grantham provides no information on how consequential the various laws are. For example, Australia's Carbon Farming Initiative Amendment Act of 2014 creates an economy-wide emissions trading system (Parliament of Australia, 2014). This seems more consequential than Israel's “Energy Resources Regulations (Energy labeling of electric heating furnaces), 1993" (State of Israel, 1993), which requires that manufacturers of electric heating furnaces and induction motors provide energy efficiency labels. Similarly, India's National Action Plan on Climate Change (Government of India, n.d.)-which contains specific targets, tax provisions, and subsidies-seems more substantial than Gambia's National Climate Change Policy (Urquhart, 2016), which is a strategy document with no concrete provisions. Because we do not know how important each law is, we have no basis for weighting them before combining them into a summary index. Without obtaining further information, we must rely on a simple count approach, as in Schmidt and Fleig (2018). The drawbacks of this approach are apparent: it is entirely possible that one well-devised climate law-say, a national carbon tax-could have a deeper impact on emissions than dozens of small-bore or aspirational policies. In terms of substantive significance, a simple count of laws could well be meaningless.

In saying this, we do not mean to criticize either the Grantham Institute or Schmidt and Fleig (2018). Assessing these laws' substantive impact would require not only fluency in many languages but also expertise in predicting the country-specific environmental impact of diverse policies. This is a herculean task. Our point, rather, is that relying on a simple count measure-however understandable-probably tells us little about climate policy. We employ this approach here because it is feasible and has been employed elsewhere. However, because this measure probably captures no meaningful variation in climate policy, we do not expect it to be systematically related to climate aid-or, for that matter, to our controls. In other words, we employ it mainly to illustrate the hazards of relying on extant climate policy measures.

In addition to the Grantham measure, we employ Steves and Teytelboym's (2013) CLIMI index. CLIMI is based on policies reported to the UNFCCC between 2005 and 2011. Policies are first sorted into four classifications-international cooperation, domestic climate framework, sector-specific measures, and crosssectoral measures-then given scores of $0, .5$, or 1 depending on how close they come to worldwide best practice. Average scores in each classification are then weighted according to the contribution each makes to worldwide emission reductions, and the weighted scores are summed. The resulting measure ranges from 0 to 1 , with higher values implying more ambitious climate policy.
CLIMI remedies some weaknesses of our Grantham measure by weighting policies according to their likely impact. However, CLIMI has serious limitations as well. Perhaps most importantly, it does not incorporate information on policy implementation: hence, CLIMI scores may reflect aspirations as much as substantive policy steps. Second, the weighting scheme is very coarse and cannot capture much of the variation in policy impact. Third, it is a pure cross-section of 95 countries, many of which are developed. This sample limitation is a particular problem when analyzing developing-world aid recipients: in our CLIMI regressions, observations range from 44 to 55 . Finally, because the CLIMI index incorporates all policies notified between 2005 and 2011-many of which were passed before 2005-we cannot match the years in which aid was received to the years in which policies were passed.

Again, the point is not to criticize Steves and Teytelboym (2013), who have taken the first steps toward aggregating diverse national policies into a single climate policy index. Rather, it is that the CLIMI index may tell us little about aid recipients' actual climate orientation or its relationship to climate aid. As with the Grantham measure, CLIMI's various sources of measurement error may mask the true relationship between climate aid and climate policy.

In sum, extant measures of climate aid and climate policy lack validity, reliability, or both. Much Rio marker "climate aid" is not actually related to climate, while available measures of climate policy may be weakly related or unrelated to governments' actual efforts to mitigate or adapt to climate change. We therefore do not expect these measures to be related to one another, beyond the occasional significance that can arise from random measurement error.

\section{Analysis and Results}

Our analysis includes all aid-eligible countries and years for which data were available for all variables. The resulting sample sizes vary widely, from a minimum of 44 in some cross-sectional CLIMI regressions to a maximum of 951 in our panel analyses. The number of countries ranges from 44 to 100 , depending on the analysis, while the longitudinal coverage is 1996 to 2009 for the Grantham analyses and 2005 to 2011 for the CLIMI analyses. ${ }^{5}$

We employ three dependent variables based on Grantham data. Climate Policy ${ }_{i t}$ is a cumulative count of country i's climate laws in year $t$. Mitigation Policy it is a cumulative count of country i's mitigation laws, and Adaptation Policy it is a cumulative count of $i$ 's adaptation laws. ${ }^{6}$ Because we include a lagged dependent variable in all panel analyses, we are predicting the likelihood that country $i$ will pass additional laws from time $t-1$ to time $t$. As a robustness check, we also employ $C L I M I_{i}$, country i's CLIMI score, as a dependent variable.

\footnotetext{
${ }^{5}$ These years refer to the dependent variable observations. Aid, which is lagged by one year, covers 1995 to 2008.

${ }^{6}$ Grantham has an explicit category for adaptation. We treat all remaining laws as mitigation-related.
} 
We employ six climate aid variables, all from AidData's PLAID 1.9.2 database (Tierney et al., 2011). In the original data, the Rio markers code projects as 0 if they have no climate relevance, 1 if climate is a significant objective, and 2 if climate is the main objective. We combine the latter two outcomes to create a dichotomous indicator of whether aid projects are climaterelated or not. We sum all climate aid for each recipient country and year, divide by population to obtain aid per capita, and log this measure to reduce skewness. ${ }^{7}$ We construct measures for both aid commitments and disbursements in case these two variables have distinct effects. ${ }^{8}$ Ln(Climate Aid Commitments ${ }_{i t-1}$ ) and Ln(Climate Aid Disbursements ${ }_{i t-1}$ ) are our first two measures of climate aid. We lag these and all other right-hand side variables by one period to ensure that the independent variables are realized before the dependent variable.

Michaelowa and Michaelowa (2011) additionally classify aid projects as mitigation-related and adaptationrelated. Using their coding, we construct four additional aid variables: $\operatorname{Ln}\left(\right.$ Mitigation Aid Commitments it-1 $_{1}$ ), Ln(Mitigation Aid Disbursements $\left.{ }_{i t-1}\right)$, Ln(Adaptation Aid Commitments Ct 1 - $_{1}$, and Ln(Adaptation Aid Disbursements $\left._{i t-1}\right)$.

We include a number of controls. First, we include $\operatorname{Ln}\left(\right.$ Other $\left.O D A_{i t-1}\right)$, recipient i's non-climate aid in year $t-1$. This is simply the log of i's total per capita ODA minus climate aid. We include this so our climate aid variables do not spuriously capture the effects of development aid more generally. ${ }^{9}$ We include $\operatorname{Ln}(G D P$ Per Capita $_{i t-1}$ ) to control for economic development, and its quadratic term, $\operatorname{Ln}\left(G D P\right.$ Per Capita $\left.{ }_{i t-1}^{2}\right)$, in case there exists an environmental Kuznets curve for climate policies. ${ }^{10}$ We include Growth $_{i t-1}$, the GDP per capita growth rate, in case faster growth makes it politically easier to pass climate legislation. ${ }^{11}$ We include Ln(Government Spending $\left._{i t-1}\right)$, logged government consumption spending as a percent of GDP, as a proxy for government ideology (left-leaning governments should spend more than right-leaning ones). ${ }^{12}$ We include $L$ (Fossil Fuels ${ }_{i t-1}$ ), the logged percent of electricity provided by oil, gas and coal, in case fossil-fuel dependency makes it harder to pass climate laws. ${ }^{13}$ We include Ln(Openness $\left.{ }_{i t-1}\right)$, logged trade as a percent of GDP, in case trade openness affects cli- mate politics by exposing carbon-intensive industries to international competition. ${ }^{14}$ We include Polity ${ }_{i t-1}$, country i's Polity score, in case domestic regime type affects the provision of climate policies. ${ }^{15}$ Finally, we include a lagged dependent variable in all panel analyses.

Because our primary dependent variable is a count of climate laws, we employ Poisson regressions, which are more appropriate for count data than linear regression. We employ recipient fixed effects in all panel analyses, which eliminates unobserved cross-national variation and allows us to focus on the within-country relationship between aid and climate policies. We also include year fixed effects to control for unobserved yearspecific shocks or trends. To reduce the influence of outliers, we perform jackknife regressions in all models. ${ }^{16}$ To address serial correlation, we employ robust countryclustered standard errors. Aid coefficients based on annual panels are shown in Figure 1.

To save space, we present our climate aid results graphically and relegate control-variable results to the Appendix. Figure 1(a) shows coefficients for the six climate aid variables when the dependent variable is all climate policies, with 95 percent confidence intervals indicated by the error bars. Figures 1 (b) and 1 (c) present the same information when the dependent variables are mitigation and adaptation policies, respectively. In nearly all cases, the error bars include the value of zero, indicated by the red vertical lines. Our measures of climate aid are thus, for the most part, not significantly related to climate policies. Of the 18 aid coefficients, only three are statistically significant. Climate aid commitments, as defined by the Rio marker, predict significantly more climate policies overall as well as more adaptation policies. One possible interpretation of these results is that they are driven by adaptation aid, which should predict adaptation but not mitigation policy. However, the results for mitigation and adaptation aid commitments cast doubt on this interpretation. Mitigation commitments predict adaptation policies but not mitigation policies, while adaptation commitments do not predict adaptation policies. This is the opposite of what we would expect if our variables were well-measured and aid was achieving its stated goals. In sum, our most consistent predictor is Riomarked climate aid-which has well-documented mea-

\footnotetext{
${ }^{7}$ We add 1 before logging to keep observations with zero aid.

${ }^{8}$ Commitments should matter more if recipients are motivated by the promise of aid, while disbursements should matter more if recipients require aid in hand to pass legislation.

${ }^{9}$ Correlations between climate and non-climate aid range from .13 to .33 .

${ }^{10} \mathrm{~A}$ number of studies find evidence of an $\mathrm{EKC}$ for $\mathrm{CO}_{2}$ emissions. See Apergis and Ozturk (2015) for a recent example.

11 Ward and Cao (2012) find that high unemployment leads to lower "green taxes," implying that recessions reduce support for environmental regulations. We employ growth rates rather than unemployment because data on the latter are unavailable for many aid recipients.

12 Ward and Cao (2012) find that left governments adopt higher levels of "green taxes," including taxes on emissions. We employ government spending as a proxy because direct ideology data are unavailable for many aid recipient.

13 Steves and Teytelboym (2013) find that a larger carbon-intensive sector leads to less stringent climate mitigation, presumably because carbon-intensive industries oppose such policies. Our measure captures consumers' interest in cheap fossil fuels as well as the interests of fossil fuel energy providers.

14 Systematic research on this point is lacking, but international competitiveness concerns are common in debates about climate mitigation. For example, in 2009, two U.S. Senators wrote in a New York Times op-ed that "climate change is real and threatens our economy and national security...[but] we cannot sacrifice another job to competitors overseas" (Kerry \& Graham, 2009).

15 Bättig and Bernauer (2009) find that democracies have a higher output of climate-friendly policies. Polity scores are from the Polity IV Project (Center for Systemic Peace, n.d.). All other controls are from the World Bank's World Development Indicators (n.d.).

16 The jackknife procedure sequentially drops each country from the data and reports the average of the estimates.
} 


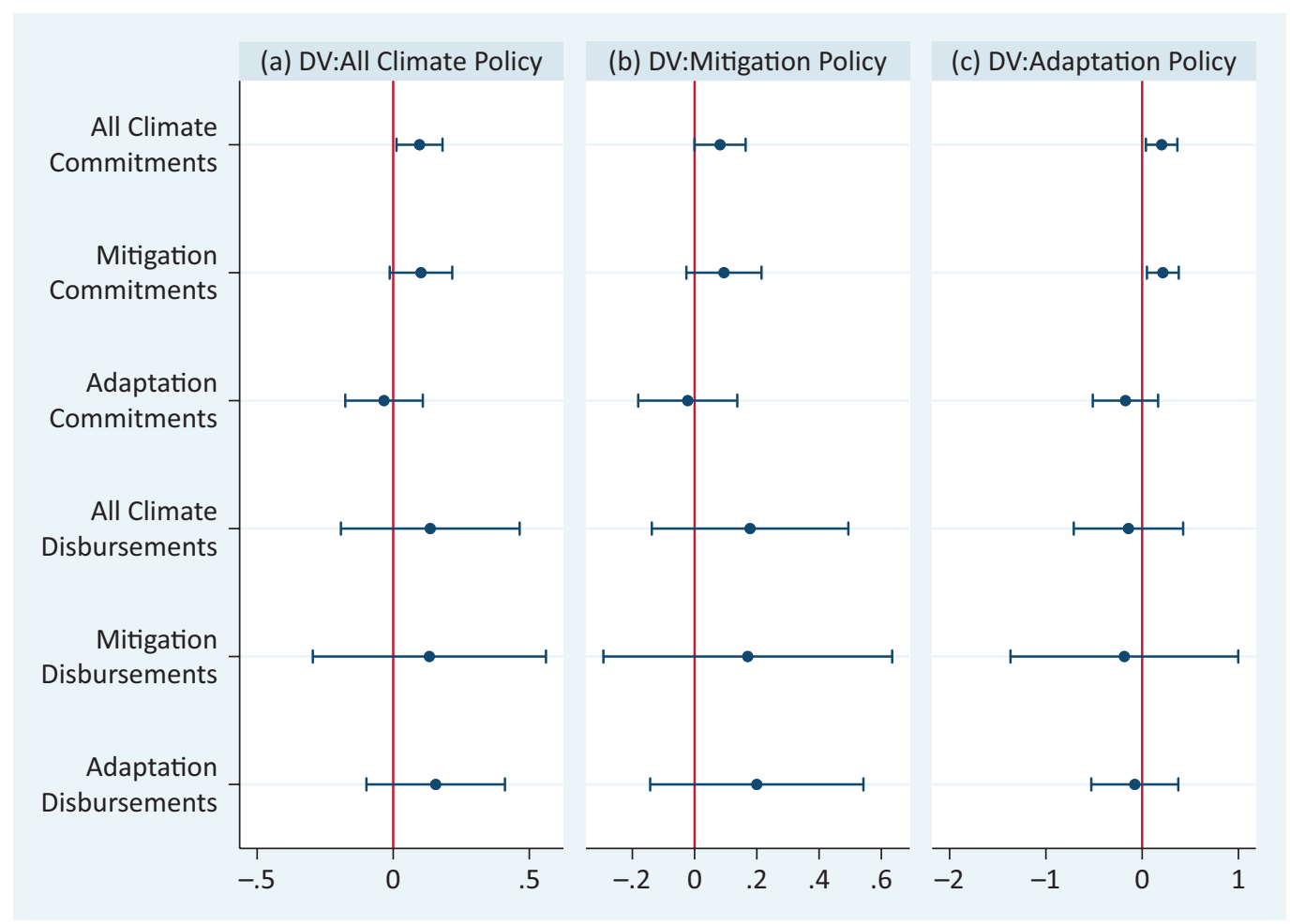

Figure 1. Climate aid and Grantham climate policy, annual panels.

surement problems-while the only other significant coefficient is anomalous. These results, along with the 15 insignificant coefficients, raise doubts about whether the few significant coefficients are substantively meaningful.

Climate policies are "sticky," in that they are not passed frequently. Regressing year-to-year changes in climate policy against year-to-year changes in foreign aid may thus not constitute a fair test. To allow for the possibility that aid affects climate policy with long and varying lags, we perform two additional analyses. First, following Knack (2004), we regress the entire-period change in climate policies - that is, the change between the first and last periods-against the whole-period average for climate aid and the controls. Both the dependent and the independent variables are thus collapsed into a single cross-section. The idea is that, while it may be difficult to match climate policy in year $t$ with aid in any particular $t-n$, countries that receive more aid over the entire period may exhibit larger changes in climate policy. Results of this analysis are shown in Figure 2.

Figure 2's structure is the same as Figure 1's, with aid variables presented on the left and sub-graphs (a), (b) and (c) showing coefficients and confidence intervals for all climate, mitigation and adaptation policies, respectively. The results are easily summarized: of the 18 coefficients, none are significant.

Second, we collapse the data into four-year panels, with each variable taking the average for each period. We thus regress average climate policy in four-year pe- riod $t$ against average aid in four-year period $t-1$. In addition to being less noisy, the four-year averages allow for longer lags in the effects of aid. Because the averaged dependent variables no longer take on integer values, we employ ordinary least-squares rather than Poisson regression for this analysis. Otherwise, it is identical to our earlier panel regressions. Results are shown in Figure 3. Again, climate aid is never significantly related to climate policy. ${ }^{17}$

As noted earlier, our Grantham measure treats all climate laws as equal, regardless of how much they matter in practice. A simple count of climate laws probably misstates the degree to which governments are addressing climate change. We thus perform additional analyses using the CLIMI measure, which weights government policies according to their likely impact. One challenge in using this measure is that it is a cross-section based on policies reported from 2005 to 2011 . Not only does it incorporate multiple reporting years, but many reported policies were passed before reporting began in 2005. This makes it difficult to say what years should be included in the cross-sectional measure of climate aid. Because the appropriate period is not obvious, we employ two for robustness, averaging climate aid for 2000-2005the five years before reporting began-and 2005-2008, the years in which reporting occurred and for which we have aid data. Results are shown in Figure 4. The CLIMI results tell the same story as previous ones: of the $12 \mathrm{cli}$ mate aid coefficients, none are significant.

\footnotetext{
17 Because the number of four-year periods in each panel is small, combining a lagged dependent variable and recipient fixed effects raises concerns about Nickell bias. We note that we obtain very similar results both with and without the lagged dependent variable and country fixed effects.
} 


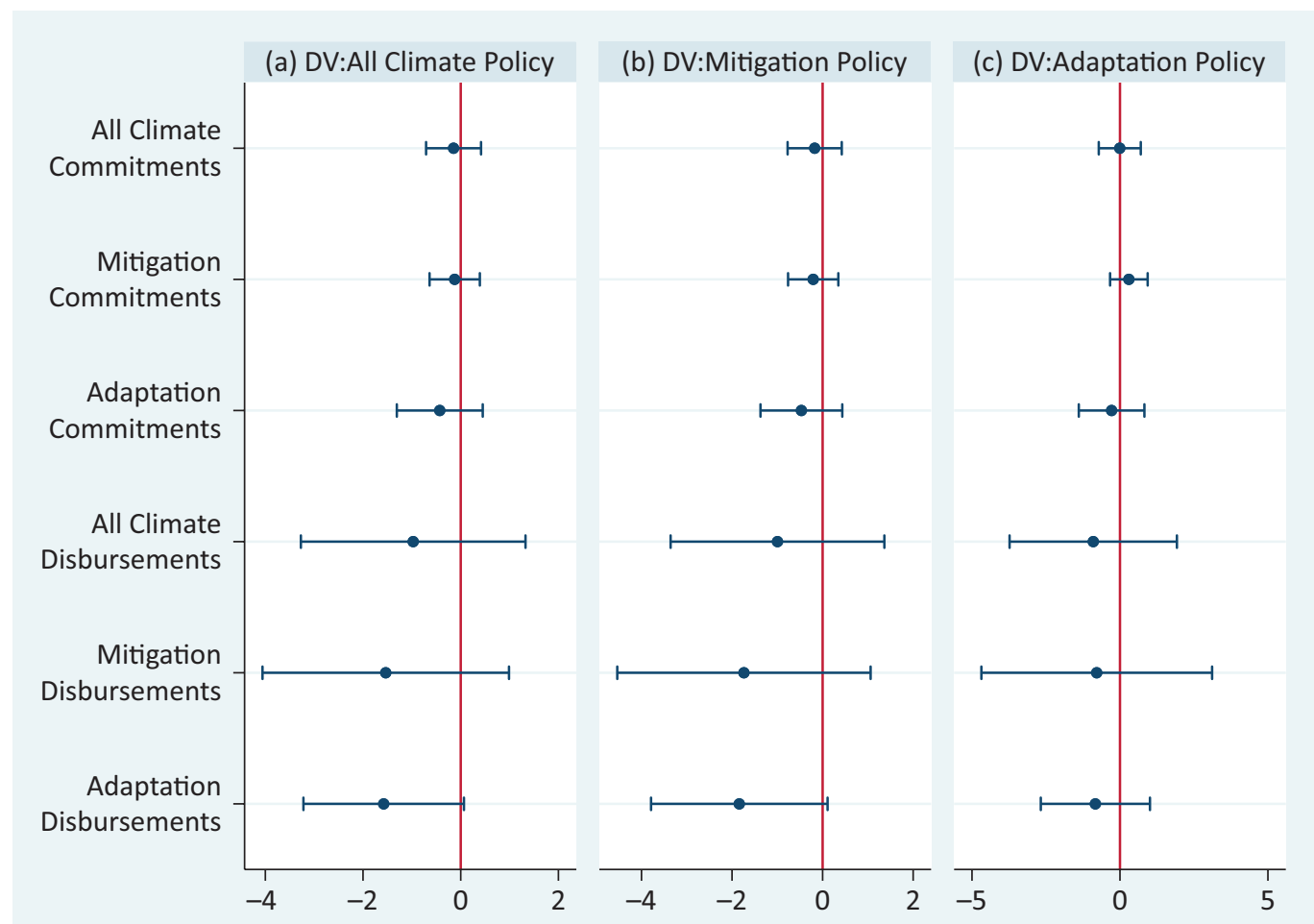

Figure 2. Climate aid and change in Grantham climate policies.

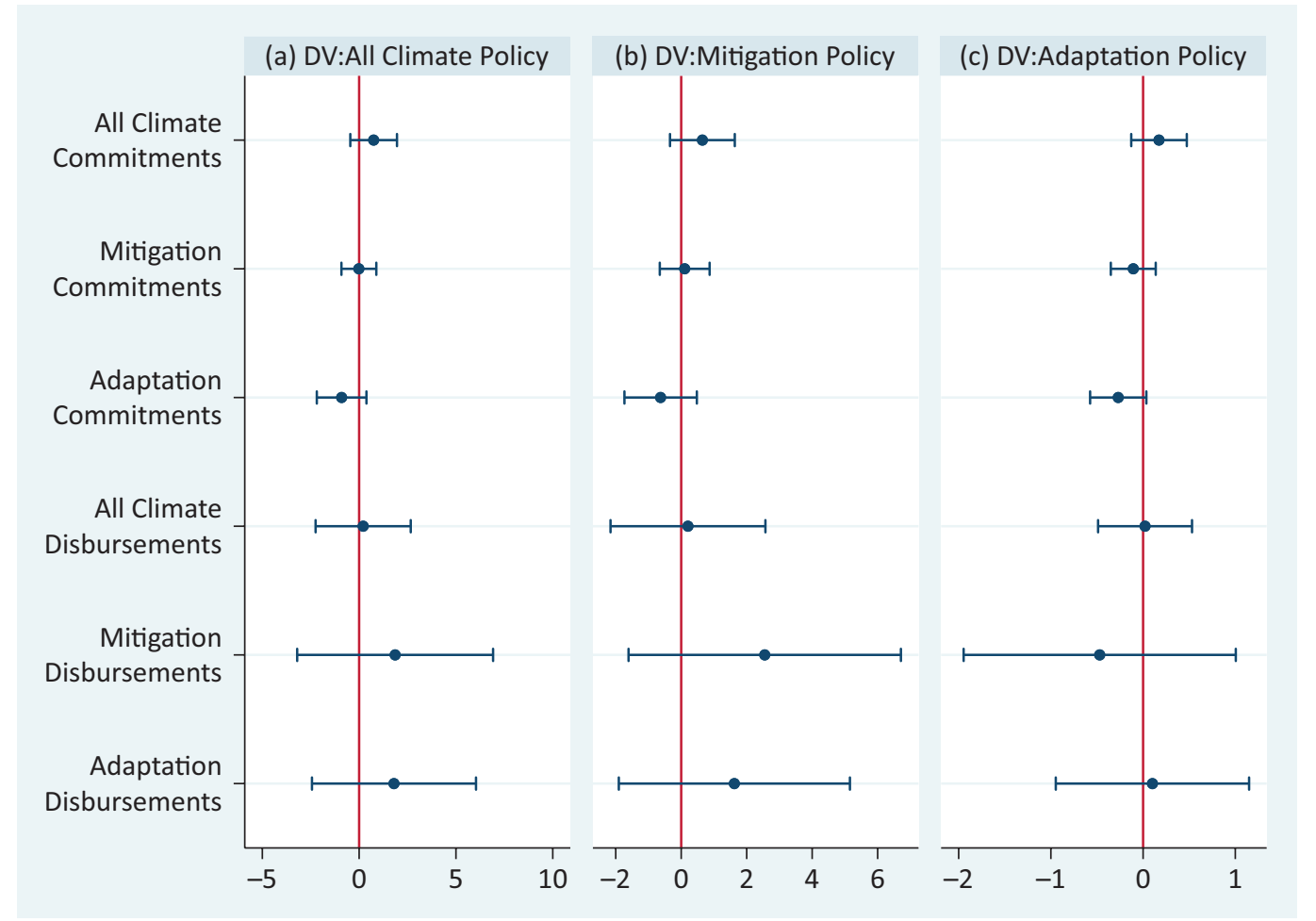

Figure 3. Climate aid and Grantham climate policy, 4-year panels. 


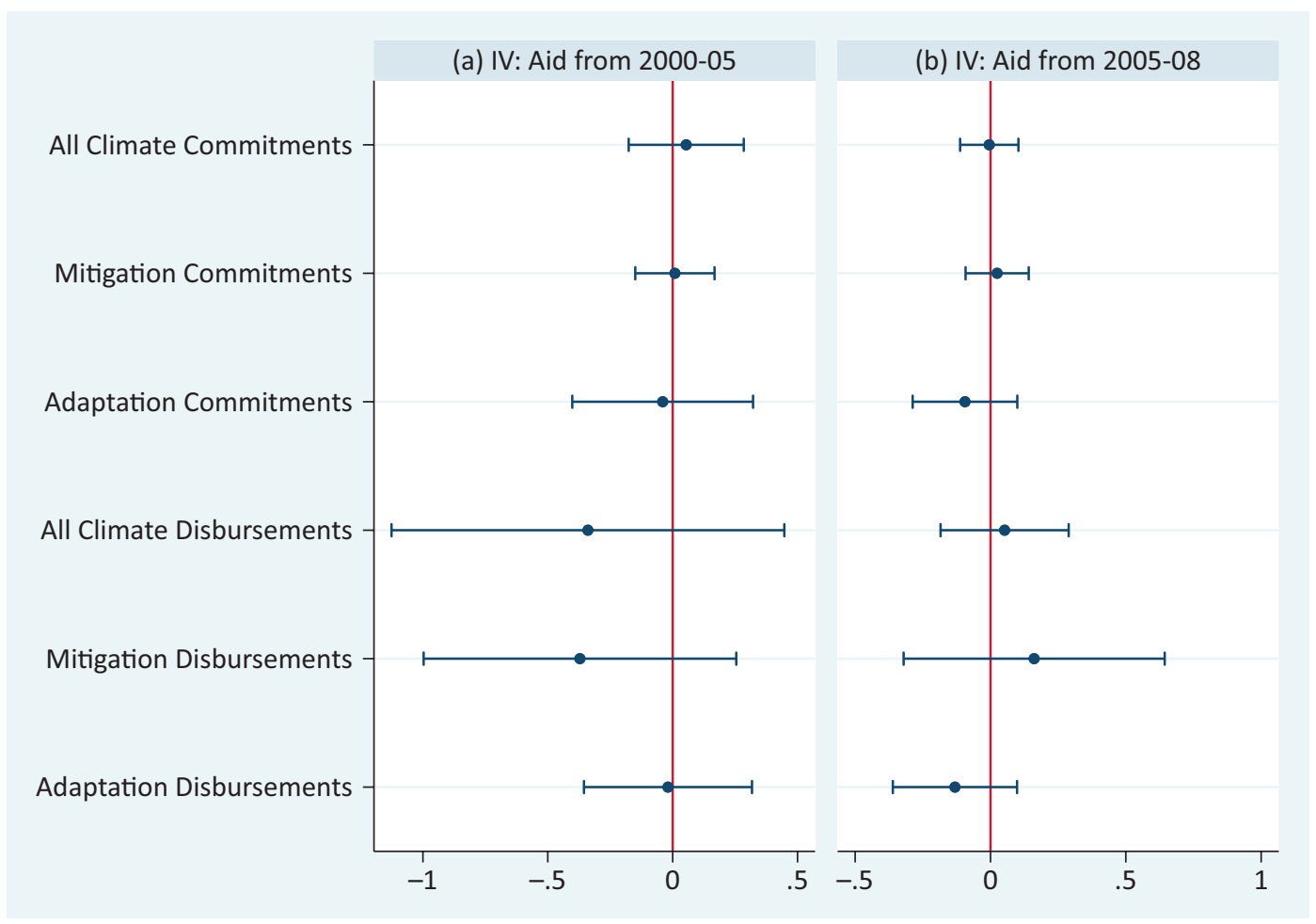

Figure 4. Climate aid and CLIMI.

In all, we estimate 66 climate aid coefficients. Of these, only three (4.5 percent) were significant. This could mean several things. First, climate aid may simply not affect climate policy. Second, the impact of aid may be masked by endogeneity bias. Research on climate aid allocation suggests that it is influenced by recipientcountry characteristics (Bagchi et al., 2016; Betzold \& Weiler, 2017; Halimanjaya \& Papyrakis, 2015; Hicks et al., 2008; Klöck et al., 2018; Weiler et al., 2018), and this nonrandom allocation could bias our results in either a positive or negative direction. As we have been unable to find an instrument that strongly predicts recipient-year variation in climate aid, we cannot rule such bias out.

Finally, we may be unable to find a relationship because our variables are poorly measured. We are inclined toward this explanation. The Grantham measure lacks validity for reasons discussed above, and while the CLIMI index is arguably more valid and reliable, its multi-year cross-sectional structure does not allow us to match it with aid (or other variables) from any particular year. The Rio markers for climate aid are also known to lack validity and reliability, and while Michaelowa and Michaelowa's (2011) aid data are arguably more accurate, this may not matter when employing dependent variables of questionable validity. In this context, it is worth noting that our control-variable results (shown in the Appendix) are nearly all insignificant as well. Since previous research suggests that these controls should matter for climate policy, this also suggests that our broadly insignificant results reflect measurement error in our dependent variable.

\section{Conclusion}

Foreign aid for climate mitigation and adaptation has risen dramatically in recent years, reflecting widespread concerns about climate change. As with all aid, it is important to assess whether climate aid "works" in the sense of actually promoting mitigation and adaptation. The central message of this article is that we are not yet in a position to make this assessment due to the poor quality of climate aid and climate policy data. Climate aid measured with Rio markers appears to lack both validity and reliability, as donors over-report their efforts to varying degrees, and there is no system in place for verifying their claims. Extant measures of climate policy also lack validity, as they do not meaningfully aggregate diverse policies into a single cross-nationally comparable metric. We wish to draw attention to these data limitations, not only because they impede our study of this important issue, but also because these data are increasingly employed in studies of both climate aid allocation (Bagchi et al., 2016; Betzold \& Weiler, 2017; Halimanjaya \& Papyrakis, 2015; Klöck et al., 2018; Weiler et al., 2018) and climate policy (Schmidt \& Fleig, 2018). We must ask whether research based on these data paint a misleading picture of developments in both policy domains.

Of these measurement problems, those involved with climate aid data should be easier to remedy. Michaelowa and Michaelowa (2011) have already made progress toward more accurately coding such aid, and other studies on this topic offer helpful suggestions (Donner et al., 2016; Junghans \& Harmeling, 2012; 
Michaelowa \& Michaelowa, 2011; Roberts \& Weikmans, 2017; Weikmans et al., 2017). Without minimizing the difficulties involved, the challenge here is essentially just identifying aid whose core purpose is clearly climaterelevant. In contrast, constructing more accurate measures of climate policy will be exceedingly difficult. Doing so will require scholars to identify the relevant provisions of diverse national policies, to estimate their likely impact on carbon emissions or other climate-related outcomes, and to aggregate these estimated effects into summary indices of climate policy. Although this task will be difficult, it is encouraging to note that scholars have accomplished similar feats in other policy domains: for example, aggregating diverse non-tariff barriers to trade into ad valorem tariff equivalents (Looi Kee et al., 2009). To reach meaningful conclusions about the aid-climate policy relationship-or climate policy more generally-scholars in this area will need to undertake similar efforts.

\section{Acknowledgments}

We thank Rachel Gisselquist and Finn Tarp for inviting us to be part of this thematic issue, and four anonymous reviewers for their helpful comments.

\section{Conflict of Interests}

The authors declare no conflict of interests.

\section{References}

AidData. (n.d.). AidData. Retrieved from https://www. aiddata.org

Apergis, N., \& Ozturk, I. (2015). Testing environmental Kuznets Curve hypothesis in Asian countries. Ecological Indicators, 52, 16-22. https://doi.org/10.1016/ J.ECOLIND.2014.11.026

Bagchi, C., Castro, P., \& Michaelowa, K. (2016). Donor accountability reconsidered: Aid allocation in the age of global public goods. Retrieved from https://www. ethz.ch/content/dam/ethz/special-interest/gess/ cis/cis-dam/Working_Papers/Ganzes\%20WP_Paula \%20Castro.pdf

Barnett, J. (2008). The effect of aid on capacity to adapt to climate change: Insights from Niue. Political Science, 60(1), 31-45. https://doi.org/10.1177/ 003231870806000104

Bättig, M. B., \& Bernauer, T. (2009). National institutions and global public goods: Are democracies more cooperative in climate change policy? International Organization, 63(2), 281. https://doi.org/10.1017/ S0020818309090092

Bernauer, T. (2013). Climate change politics. Annual Review of Political Science, 16(1), 421-448. https://doi. org/10.1146/annurev-polisci-062011-154926

Betzold, C., \& Weiler, F. (2017). Allocation of aid for adaptation to climate change: Do vulnerable countries receive more support? International Environmental Agreements: Politics, Law and Economics, 17(1), pp. 17-36. https://doi.org/10.1007/s10784-016-9343-8

Center for Systemic Peace. (n.d.). The Polity Project. Center for Systemic Peace. Retrieved from http://www. systemicpeace.org/polityproject.html

Chao, C.-C., \& Yu, E. S. H. (1999). Foreign aid, the environment, and welfare (Vol. 59). Retrieved from https://ac.els-cdn.com/S0304387899000255/1-s2. 0-S0304387899000255-main.pdf?_tid=7d06131ee848-481f-b1b9-375de321c2a2\&acdnat= 1548369206 f29dcbf2f0f53cb6f79651864772e2bb

Chen, Z., \& He, J. (2013). Foreign aid for climate change related capacity building (UNU-WIDER Working Paper, No. 46). Retrieved from https://www.econstor. eu/handle/10419/80937

Connolly, B. (1996). Increments for the Earth: The politics of environmental aid. In R. O. Keohane \& M. A. Levy (Eds.), Institutions for environmental aid. Cambridge, MA: MIT Press.

Donner, S. D., Kandlikar, M., \& Webber, S. (2016). Measuring and tracking the flow of climate change adaptation aid to the developing world. Environmental Research Letters, 11(5). https://doi.org/10.1088/17489326/11/5/054006

Eyckmans, J., Fankhauser, S., \& Kverndokk, S. (2016). Development aid and climate finance. Environmental and Resource Economics, 63(2), 429-450. https://doi. org/10.1007/s10640-015-9883-3

Government of India. (n.d.). National action plan on climate change. Retrieved from http://www.Ise.ac.uk/ GranthamInstitute/wp-content/uploads/laws/ 1320.pdf

Grantham Institute. (n.d.). Climate change laws of the world. Grantham Institute. Retrieved from http:// www.Ise.ac.uk/GranthamInstitute/climate-changelaws-of-the-world

Halimanjaya, A., \& Papyrakis, E. (2015). Donor characteristics and the allocation of aid to climate mitigation finance. Climate Change Economics, 6(3). https://doi. org/10.1142/S2010007815500141

Hatzipanayotou, P., Lahiri, S., \& Michael, M. S. (2002). Can cross-border pollution reduce pollution? Canadian Journal of Economics/Revue Canadienne D'Economique, 35(4), 805-818. https://doi.org/ 10.1111/1540-5982.00155

Hicks, R. L., Parks, B. C., Roberts, J. T., \& Tierney, M. J. (2008). Greening aid? Understanding the environmental impact of development assistance. Oxford: Oxford University Press. https://doi.org/10.1093/ acprof:oso/9780199213948.001.0001

Junghans, L., \& Harmeling, S. (2012). Different tales from different countries: A first assessment of the OECD "Adaptation Marker". Bonn: Germanwatch. Retrieved from https://germanwatch.org/ sites/germanwatch.org/files/publication/7083.pdf

Kee, H. L., Nicita, A., \& Olarreaga, M. (2009). Estimating trade restrictiveness indices. The Economic Journal, 
119(534), 172-199. https://doi.org/10.1111/j.14680297.2008.02209.x

Kerry, J., \& Graham, L. (2009). Yes we can (pass climate change legislation). The New York Times. Retrieved from https://www.nytimes.com/2009/10/ 11/opinion/11kerrygraham.html

Klöck, C., Molenaers, N., \& Weiler, F. (2018). Responsibility, capacity, greenness or vulnerability? What explains the levels of climate aid provided by bilateral donors? Environmental Politics, 27(5), 892-916. https://doi.org/10.1080/09644016.2018.1480273

Knack, S. (2004). Does foreign aid promote democracy? International Studies Quarterly, 48(1), 251-266. https://doi.org/10.1111/j.0020-8833.2004.00299.x

Mak Arvin, B., Dabir-Alai, P., \& Lew, B. (2006). Does foreign aid affect the environment in developing countries? Journal of Economic Development, 63. Retrieved from https://s3.amazonaws.com/academia. edu.documents/3687563/31-1-5.pdf?AWSAccess Keyld=AKIAIWOWYYGZ2Y53UL3A\&Expires $=154837$ 2177\&Signature=h\%2FIKGNOtbV\%2BU4fEOQcgu1v BX2i0\%3D\&response-content-disposition=inline\%3B filename\%3DDoes_Foreign_Aid_Affect_the Environmen

Marcoux, C., Parks, B. C., Peratsakis, C. M., Roberts, J. T., \& Tierney, M. J. (2013). Environmental and climate finance in a new world: How past environmental aid allocation impacts future climate aid (UNU-WIDER Working Paper, No. 128). Retrieved from https:// www.econstor.eu/handle/10419/93727

Masson-Delmotte, V., Zhai, P., Pörtner, H.-O., Roberts, D., Skea, J., Shukla, P. R., . . . Waterfield, T. (Eds.). (2018). Summary for policymakers. In Global warming of $1.5^{\circ} \mathrm{C}$. Geneva: Intergovernmental Panel on Climate Change. Retrieved from https://www.ipcc.ch/ sr15/chapter/summary-for-policy-makers

Michaelowa, A., \& Michaelowa, K. (2011). Coding error or statistical embellishment? The political economy of reporting climate aid. World Development, 39(11), 2010-2020. https://doi.org/10.1016/ J.WORLDDEV.2011.07.020

Neumayer, E. (2002). Do democracies exhibit stronger international environmental commitment? A crosscountry analysis. Journal of Peace Research, 39(2), 139-164. https://doi.org/10.1177/0022343302039 002001

Organisation for Economic Co-operation and Development. (n.d.). Climate change: OECD DAC external development finance statistics. Organisation for Economic Co-operation and Development. Retrieved from http://www.oecd.org/dac/financingsustainable-development/development-financetopics/climate-change.htm

Parliament of Australia. (2014). Carbon farming initiative amendment Act 2014. Retrieved from http://www.Ise.ac.uk/GranthamInstitute/wpcontent/uploads/laws/1031.pdf

Qian, N. (2015). Making progress on foreign aid. Annual
Review of Economics, 7(1), 277-308. https://doi.org/ 10.1146/annurev-economics-080614-115553

Republic of Mali. (2011). Decree No. 2011-107-PM-RM of March 11, 2011 establishing the National Climate Change Committee of Mali. Retrieved from http:// www.Ise.ac.uk/Granthamlnstitute/law/decree-no2011-107-pm-rm-of-march-11-2011-establishingthe-national-climate-change-committee-of-mali

Roberts, J. T., Starr, K., Jones, T., \& Abdel-Fattah, D. (2008). The reality of official climate aid (Oxford Energy and Environment Comment, November 2008). Oxford: Oxford Institute for Energy Studies. Retrieved from https://www.oxfordenergy.org/wpcms/wpcontent/uploads/2011/01/November2008ClimateAid-BenitoMuller-.pdf

Roberts, J. T., \& Weikmans, R. (2017). Postface: Fragmentation, failing trust and enduring tensions over what counts as climate finance. International Environmental Agreements: Politics, Law and Economics, 17(1), 129-137. https://doi.org/10.1007/ s10784-016-9347-4

Schmidt, N. M., \& Fleig, A. (2018). Global patterns of national climate policies: Analyzing 171 country portfolios on climate policy integration. Environmental Science \& Policy, 84, 177-185. https://doi.org/10.1016/ J.ENVSCI.2018.03.003

State of Israel. (1993). Energy resources regulations (energy labeling of electric heating furnaces), 1993. Retrieved from http://www.lse.ac.uk/Grantham Institute/law/energy-resources-regulations-energylabeling-of-electric-heating-furnaces-1993

Steves, F., \& Teytelboym, A. (2013). Political economy of climate change policy (SSEE Working Paper, No. 13-02). Oxford: SSEE. https://doi.org/10.2139/ssrn. 2456538

Tierney, M. J., Nielson, D. L., Powers, R. M., Parks, B., Wilson, S. E., \& Hicks, R. L. (2011). More dollars than sense: Refining our knowledge of development finance using AidData. World Development, 39(11), 1891-1906. https://doi.org/10.1016/J.WORLDDEV. 2011.07.029

United Nations Framework Convention on Climate Change. (2015). Paris agreement. New York, NY: United Nations. Retrieved from https://unfccc.int/ sites/default/files/english_paris_agreement.pdf

Urquhart, P. (2016). National climate change policy of the Gambia. Banjul: Department of Water Resources. Retrieved from http://www.lse.ac.uk/Grantham Institute/wp-content/uploads/laws/8109.pdf

Victor, D. (2013). Foreign aid for capacity-building to address climate change: Insights and applications (UNUWIDER, No. 2013/084). Retrieved from www.wider. unu.edu

Vietnam Law \& Legal Forum. (2011). Decision No. $37 / 2011 / Q D-T T g$ providing the mechanism to support the development of wind power projects in Vietnam. Retrieved from http://vietnamlawmagazine. vn/gazette.html\#vnlpositionyl 
von Stein, J. (2008). The international law and politics of climate change. Journal of Conflict Resolution, 52(2), 243-268. https://doi.org/10.1177/ 0022002707313692

Ward, H., \& Cao, X. (2012). Domestic and international influences on green taxation. Comparative Political Studies, 45(9), 1075-1103. https://doi.org/10.1177/ 0010414011434007

Weikmans, R., Roberts, J. T., Baum, J., Bustos, M. C., \& Durand, A. (2017). Development in practice assessing the credibility of how climate adaptation aid projects are categorised. Development in Practice, 27(4), 458-471. https://doi.org/10.1080/09614524. 2017.1307325

Weiler, F., Klöck, C., \& Dornan, M. (2018). Vulnerabil- ity, good governance, or donor interests? The allocation of aid for climate change adaptation. World Development, 104, 65-77. https://doi.org/10.1016/ J.WORLDDEV.2017.11.001

World Bank. (n.d.). World development indicators. World Bank. Retrieved from https://datacatalog.worldbank. org/dataset/world-development-indicators

World Bank. (2005). Improving the World Bank's development effectiveness: What does evaluation show? Washington, DC: World Bank. Retrieved from http:// www.albacharia.ma/xmlui/bitstream/handle/12345 6789/30399/0142Improving the World Bank's Development Effectiveness - What Does Evaluation Show.pdf?sequence=1

\section{About the Authors}

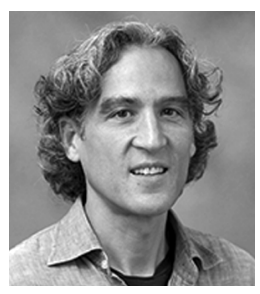

Daniel Yuichi Kono is a Professor of Political Science at the University of California - Davis. His research focuses on the political economy of international trade, foreign aid and climate change. He has published articles in the American Political Science Review, Comparative Political Studies, International Studies Quarterly, The Journal of Politics, and other journals.

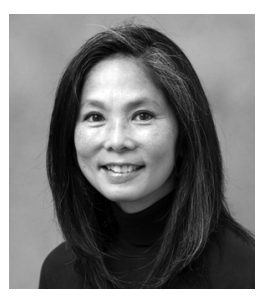

Gabriella R. Montinola is an Associate Professor of Political Science at the University of California - Davis. Her research focuses on the impact of foreign aid and migrant remittances on governance and development in the developing world. She has published articles in the British Journal of Political Science, Comparative Political Studies, Journal of Politics, Studies for Comparative International Development, and other journals. 


\section{Appendix}

Table A0. Summary statistics.

\begin{tabular}{|c|c|c|c|c|c|}
\hline Variable & Obs. & Mean & S.D. & Min. & Max. \\
\hline Climate Policy $_{i t}$ & 951 & 3.32 & 4.37 & 0 & 34 \\
\hline Mitigation Policy $_{i t}$ & 951 & 2.91 & 3.93 & 0 & 29 \\
\hline Adaptation Policy $_{i t}$ & 951 & 0.41 & 0.80 & 0 & 6 \\
\hline CLIMli & 55 & 0.30 & 0.18 & 0.02 & 0.70 \\
\hline Ln(Climate Aid Commitments $\left.{ }_{i t}\right)$ & 756 & 0.42 & 0.62 & 0 & 3.80 \\
\hline Ln(Mitigation Aid Commitments ${ }_{i t}$ ) & 862 & 0.34 & 0.61 & 0 & 3.80 \\
\hline Ln(Adaptation Aid Commitments ${ }_{i t}$ ) & 862 & 0.21 & 0.44 & 0 & 3.91 \\
\hline Ln(Climate Aid Disbursements $\left.{ }_{i t}\right)$ & 741 & 0.08 & 0.17 & 0 & 1.36 \\
\hline Ln(Mitigation Aid Disbursements ${ }_{i t}$ ) & 831 & 0.04 & 0.12 & 0 & 1.11 \\
\hline Ln(Adaptation Aid Disbursements ${ }_{i t}$ ) & 852 & 0.07 & 0.21 & 0 & 3.61 \\
\hline Ln(Other ODA $\left.{ }_{i t}\right)$ (Commitments) & 862 & 3.78 & 0.95 & 0.65 & 6.99 \\
\hline Ln(Other ODA $\left.{ }_{i t}\right)$ (Disbursements) & 813 & 1.89 & 1.16 & 0.03 & 6.61 \\
\hline Ln(GDP Per Capita $\left.{ }_{i t}\right)$ & 951 & 7.84 & 1.01 & 5.35 & 10.19 \\
\hline Ln(GDP Per Capita $\left.{ }_{i t}^{2}\right)$ & 951 & 62.40 & 15.62 & 28.58 & 103.74 \\
\hline Growth $_{i t}$ & 951 & 3.13 & 4.54 & -19.06 & 33.03 \\
\hline Ln(Government Spending $\left.{ }_{i t}\right)$ & 950 & 2.60 & 0.39 & 0.72 & 4.24 \\
\hline Ln(Fossil Fuels $\left.{ }_{i t}\right)$ & 947 & 3.62 & 1.43 & -3.83 & 4.61 \\
\hline $\operatorname{Ln}$ Openness $\left.{ }_{i t}\right)$ & 951 & 4.23 & 0.43 & 2.75 & 5.30 \\
\hline Polity $_{i t}$ & 951 & 3.64 & 5.82 & -9 & 10 \\
\hline
\end{tabular}


COGITATIO

Table A1(a). Climate aid and Grantham climate policy, annual panels.

\begin{tabular}{|c|c|c|c|c|c|c|}
\hline & \multicolumn{6}{|c|}{ Climate Aid Variable } \\
\hline & $\begin{array}{c}\text { All Climate } \\
\text { Commitments } \\
\text { (Rio) }\end{array}$ & $\begin{array}{c}\text { Mitigation } \\
\text { Commitments } \\
\text { (Michaelowa) }\end{array}$ & $\begin{array}{l}\text { Adaptation } \\
\text { Commitments } \\
\text { (Michaelowa) }\end{array}$ & $\begin{array}{c}\text { All Climate } \\
\text { Disbursements } \\
\text { (Rio) }\end{array}$ & $\begin{array}{c}\text { Mitigation } \\
\text { Disbursements } \\
\text { (Michaelowa) }\end{array}$ & $\begin{array}{c}\text { Adaptation } \\
\text { Disbursements } \\
\text { (Michaelowa) }\end{array}$ \\
\hline Climate Policy $_{i t-1}$ & $\begin{array}{l}0.06 * * \\
(0.01)\end{array}$ & $\begin{array}{c}0.04 \\
(0.03)\end{array}$ & $\begin{array}{c}0.04 \\
(0.03)\end{array}$ & $\begin{array}{l}0.05^{* *} \\
(0.01)\end{array}$ & $\begin{array}{l}0.05^{* *} \\
(0.02)\end{array}$ & $\begin{array}{c}0.05^{*} \\
(0.02)\end{array}$ \\
\hline Ln(GDP Per Capita $\left.{ }_{i t-1}\right)$ & $\begin{array}{c}-1.02 \\
(3.29)\end{array}$ & $\begin{array}{c}-3.24 \\
(3.45)\end{array}$ & $\begin{array}{c}-3.02 \\
(3.54)\end{array}$ & $\begin{array}{c}-1.41 \\
(2.93)\end{array}$ & $\begin{array}{r}-1.72 \\
(3.85)\end{array}$ & $\begin{array}{c}-2.64 \\
(3.70)\end{array}$ \\
\hline Ln(GDP Per Capita ${ }_{i t-1}^{2}$ ) & $\begin{array}{c}0.12 \\
(0.21)\end{array}$ & $\begin{array}{c}0.24 \\
(0.22)\end{array}$ & $\begin{array}{c}0.22 \\
(0.22)\end{array}$ & $\begin{array}{c}0.16 \\
(0.19)\end{array}$ & $\begin{array}{c}0.16 \\
(0.25)\end{array}$ & $\begin{array}{c}0.22 \\
(0.24)\end{array}$ \\
\hline Growth $_{i t-1}$ & $\begin{array}{c}-0.00 \\
(0.01)\end{array}$ & $\begin{array}{c}0.00 \\
(0.01)\end{array}$ & $\begin{array}{c}0.00 \\
(0.01)\end{array}$ & $\begin{array}{c}-0.00 \\
(0.01)\end{array}$ & $\begin{array}{c}0.00 \\
(0.01)\end{array}$ & $\begin{array}{c}-0.01 \\
(0.01)\end{array}$ \\
\hline Ln(Government Spending $\left.{ }_{i t-1}\right)$ & $\begin{array}{c}-0.31 \\
(0.23)\end{array}$ & $\begin{array}{c}-0.19 \\
(0.31)\end{array}$ & $\begin{array}{r}-0.19 \\
(0.31)\end{array}$ & $\begin{array}{c}-0.37 \\
(0.23)\end{array}$ & $\begin{array}{c}-0.35 \\
(0.26)\end{array}$ & $\begin{array}{c}-0.22 \\
(0.28)\end{array}$ \\
\hline $\operatorname{Ln}\left(\right.$ Fossil Fuels $\left._{i t-1}\right)$ & $\begin{array}{c}-0.04 \\
(0.07)\end{array}$ & $\begin{array}{c}-0.02 \\
(0.08) \\
\end{array}$ & $\begin{array}{c}-0.02 \\
(0.08) \\
\end{array}$ & $\begin{array}{c}-0.05 \\
(0.06) \\
\end{array}$ & $\begin{array}{c}-0.02 \\
(0.08)\end{array}$ & $\begin{array}{r}-0.02 \\
(0.08)\end{array}$ \\
\hline $\operatorname{Ln}\left(\right.$ Openness $\left.s_{i t-1}\right)$ & $\begin{array}{c}0.02 \\
(0.27)\end{array}$ & $\begin{array}{c}0.33 \\
(0.31)\end{array}$ & $\begin{array}{c}0.34 \\
(0.32)\end{array}$ & $\begin{array}{c}-0.06 \\
(0.27)\end{array}$ & $\begin{array}{c}0.20 \\
(0.28)\end{array}$ & $\begin{array}{c}0.21 \\
(0.28)\end{array}$ \\
\hline Polity $_{i t-1}$ & $\begin{array}{c}-0.00 \\
(0.03)\end{array}$ & $\begin{array}{c}0.01 \\
(0.02)\end{array}$ & $\begin{array}{c}0.01 \\
(0.03)\end{array}$ & $\begin{array}{c}-0.01 \\
(0.02)\end{array}$ & $\begin{array}{c}0.01 \\
(0.03)\end{array}$ & $\begin{array}{c}0.01 \\
(0.03)\end{array}$ \\
\hline $\operatorname{Ln}\left(\right.$ Other ODA $\left.A_{i t-1}\right)$ & $\begin{array}{c}0.05 \\
(0.06)\end{array}$ & $\begin{array}{c}-0.00 \\
(0.09)\end{array}$ & $\begin{array}{c}0.01 \\
(0.09)\end{array}$ & $\begin{array}{c}-0.04 \\
(0.04)\end{array}$ & $\begin{array}{c}-0.04 \\
(0.04)\end{array}$ & $\begin{array}{r}-0.02 \\
(0.03)\end{array}$ \\
\hline $\operatorname{Ln}\left(\right.$ Climate Aid $\left._{i t-1}\right)$ & $\begin{array}{c}0.10 * \\
(0.04)\end{array}$ & $\begin{array}{c}0.10 \\
(0.06)\end{array}$ & $\begin{array}{c}-0.03 \\
(0.07)\end{array}$ & $\begin{array}{c}0.14 \\
(0.16)\end{array}$ & $\begin{array}{c}0.13 \\
(0.21)\end{array}$ & $\begin{array}{c}0.16 \\
(0.13)\end{array}$ \\
\hline Observations (Countries) & $775(74)$ & $951(83)$ & $951(83)$ & $751(74)$ & $845(75)$ & $875(75)$ \\
\hline$F($ Prob $>F)$ & $25.0(.000)$ & $15.7(.000)$ & $13.9(.000)$ & $42.8(.000)$ & $29.5(.000)$ & $20.3(.000)$ \\
\hline
\end{tabular}

Notes: Dependent variable: Climate Policy ${ }_{i t}$; Robust (country-clustered) standard errors in parentheses, $* * p<.01 * \mathrm{p}<.05$; All models include country and year fixed effects. 
COGITATIO

Table A1(b). Climate aid and Grantham mitigation policy, annual panels.

\begin{tabular}{|c|c|c|c|c|c|c|}
\hline & \multicolumn{6}{|c|}{ Climate Aid Variable } \\
\hline & $\begin{array}{c}\text { All Climate } \\
\text { Commitments } \\
\text { (Rio) }\end{array}$ & $\begin{array}{c}\text { Mitigation } \\
\text { Commitments } \\
\text { (Michaelowa) }\end{array}$ & $\begin{array}{l}\text { Adaptation } \\
\text { Commitments } \\
\text { (Michaelowa) }\end{array}$ & $\begin{array}{c}\text { All Climate } \\
\text { Disbursements } \\
\text { (Rio) }\end{array}$ & $\begin{array}{c}\text { Mitigation } \\
\text { Disbursements } \\
\text { (Michaelowa) }\end{array}$ & $\begin{array}{c}\text { Adaptation } \\
\text { Disbursements } \\
\text { (Michaelowa) }\end{array}$ \\
\hline Climate Policy $_{i t-1}$ & $\begin{array}{l}0.06 * * \\
(0.01)\end{array}$ & $\begin{array}{c}0.03 \\
(0.04)\end{array}$ & $\begin{array}{c}0.04 \\
(0.04)\end{array}$ & $\begin{array}{l}0.05^{* *} \\
(0.01)\end{array}$ & $\begin{array}{l}0.06^{* *} \\
(0.02)\end{array}$ & $\begin{array}{c}0.05^{*} \\
(0.02)\end{array}$ \\
\hline Ln(GDP Per Capita $\left.{ }_{i t-1}\right)$ & $\begin{array}{c}-0.73 \\
(2.92)\end{array}$ & $\begin{array}{c}-2.77 \\
(3.19)\end{array}$ & $\begin{array}{c}-2.59 \\
(3.29)\end{array}$ & $\begin{array}{c}-0.88 \\
(2.61)\end{array}$ & $\begin{array}{r}-1.11 \\
(3.39)\end{array}$ & $\begin{array}{c}-2.06 \\
(3.28)\end{array}$ \\
\hline Ln(GDP Per Capita ${ }_{i t-1}^{2}$ ) & $\begin{array}{c}0.12 \\
(0.19)\end{array}$ & $\begin{array}{c}0.21 \\
(0.20)\end{array}$ & $\begin{array}{c}0.20 \\
(0.21)\end{array}$ & $\begin{array}{c}0.13 \\
(0.17)\end{array}$ & $\begin{array}{c}0.12 \\
(0.22)\end{array}$ & $\begin{array}{c}0.19 \\
(0.22)\end{array}$ \\
\hline Growth $_{i t-1}$ & $\begin{array}{c}-0.01 \\
(0.01)\end{array}$ & $\begin{array}{c}-0.00 \\
(0.01)\end{array}$ & $\begin{array}{c}-0.00 \\
(0.01)\end{array}$ & $\begin{array}{c}-0.01 \\
(0.01)\end{array}$ & $\begin{array}{r}-0.00 \\
(0.01)\end{array}$ & $\begin{array}{c}-0.01 \\
(0.01)\end{array}$ \\
\hline Ln(Government Spending ${ }_{i t-1}$ ) & $\begin{array}{c}-0.27 \\
(0.22)\end{array}$ & $\begin{array}{c}-0.14 \\
(0.31)\end{array}$ & $\begin{array}{c}-0.13 \\
(0.31)\end{array}$ & $\begin{array}{c}-0.34 \\
(0.22)\end{array}$ & $\begin{array}{c}-0.29 \\
(0.25)\end{array}$ & $\begin{array}{c}-0.16 \\
(0.28)\end{array}$ \\
\hline $\operatorname{Ln}\left(\right.$ Fossil Fuels $\left._{i t-1}\right)$ & $\begin{array}{c}-0.03 \\
(0.07) \\
\end{array}$ & $\begin{array}{c}-0.01 \\
(0.08) \\
\end{array}$ & $\begin{array}{c}-0.02 \\
(0.08) \\
\end{array}$ & $\begin{array}{c}-0.03 \\
(0.06) \\
\end{array}$ & $\begin{array}{c}-0.01 \\
(0.09) \\
\end{array}$ & $\begin{array}{r}-0.01 \\
(0.09)\end{array}$ \\
\hline Ln(Openness $\left.{ }_{i t-1}\right)$ & $\begin{array}{c}0.17 \\
(0.27)\end{array}$ & $\begin{array}{c}0.47 \\
(0.33)\end{array}$ & $\begin{array}{c}0.47 \\
(0.34)\end{array}$ & $\begin{array}{c}0.05 \\
(0.27)\end{array}$ & $\begin{array}{c}0.30 \\
(0.28)\end{array}$ & $\begin{array}{c}0.33 \\
(0.28)\end{array}$ \\
\hline Polity $_{i t-1}$ & $\begin{array}{c}-0.00 \\
(0.02)\end{array}$ & $\begin{array}{c}0.01 \\
(0.02)\end{array}$ & $\begin{array}{c}0.01 \\
(0.02)\end{array}$ & $\begin{array}{c}-0.01 \\
(0.02)\end{array}$ & $\begin{array}{c}0.01 \\
(0.02)\end{array}$ & $\begin{array}{c}0.01 \\
(0.02)\end{array}$ \\
\hline $\operatorname{Ln}\left(\right.$ Other ODA $\left.A_{i t-1}\right)$ & $\begin{array}{c}0.05 \\
(0.06)\end{array}$ & $\begin{array}{c}-0.00 \\
(0.09)\end{array}$ & $\begin{array}{c}0.01 \\
(0.09)\end{array}$ & $\begin{array}{c}-0.04 \\
(0.04)\end{array}$ & $\begin{array}{c}-0.04 \\
(0.04)\end{array}$ & $\begin{array}{r}-0.02 \\
(0.03)\end{array}$ \\
\hline $\operatorname{Ln}\left(\right.$ Climate Aid $\left._{i t-1}\right)$ & $\begin{array}{c}0.08 \\
(0.04)\end{array}$ & $\begin{array}{c}0.09 \\
(0.06)\end{array}$ & $\begin{array}{c}-0.02 \\
(0.08)\end{array}$ & $\begin{array}{c}0.18 \\
(0.16)\end{array}$ & $\begin{array}{c}0.17 \\
(0.23)\end{array}$ & $\begin{array}{c}0.20 \\
(0.17)\end{array}$ \\
\hline Observations (Countries) & $767(73)$ & $942(82)$ & $942(82)$ & $743(73)$ & $836(74)$ & $867(74)$ \\
\hline$F($ Prob $>F)$ & $24.9(.000)$ & $14.6(.000)$ & $13.0(.000)$ & $26.4(.000)$ & $24.7(.000)$ & $21.2(.000)$ \\
\hline
\end{tabular}

Notes: Dependent variable: Mitigation Policy ${ }_{i t}$; Robust (country-clustered) standard errors in parentheses, $* * p<.01 * p<.05 ;$ All models include country and year fixed effects. 
COGITATIO

Table A1(c). Climate aid and Grantham adaptation policy, annual panels.

\begin{tabular}{|c|c|c|c|c|c|c|}
\hline & \multicolumn{6}{|c|}{ Climate Aid Variable } \\
\hline & $\begin{array}{c}\text { All Climate } \\
\text { Commitments } \\
\text { (Rio) }\end{array}$ & $\begin{array}{c}\text { Mitigation } \\
\text { Commitments } \\
\text { (Michaelowa) }\end{array}$ & $\begin{array}{c}\text { Adaptation } \\
\text { Commitments } \\
\text { (Michaelowa) }\end{array}$ & $\begin{array}{c}\text { All Climate } \\
\text { Disbursements } \\
\text { (Rio) }\end{array}$ & $\begin{array}{c}\text { Mitigation } \\
\text { Disbursements } \\
\text { (Michaelowa) }\end{array}$ & $\begin{array}{c}\text { Adaptation } \\
\text { Disbursements } \\
\text { (Michaelowa) }\end{array}$ \\
\hline Climate Policy $_{i t-1}$ & $\begin{array}{c}0.24 \\
(0.13)\end{array}$ & $\begin{array}{c}0.20 \\
(0.13)\end{array}$ & $\begin{array}{c}0.23 \\
(0.12)\end{array}$ & $\begin{array}{c}0.27^{*} \\
(0.13)\end{array}$ & $\begin{array}{c}0.30 * \\
(0.13)\end{array}$ & $\begin{array}{c}0.25 \\
(0.14)\end{array}$ \\
\hline Ln(GDP Per Capita $\left.{ }_{i t-1}\right)$ & $\begin{array}{c}-5.64 \\
(7.21)\end{array}$ & $\begin{array}{c}-7.93 \\
(7.31)\end{array}$ & $\begin{array}{c}-7.04 \\
(7.25)\end{array}$ & $\begin{array}{c}-8.72 \\
(6.98)\end{array}$ & $\begin{array}{c}-7.15 \\
(7.86)\end{array}$ & $\begin{array}{r}-7.55 \\
(7.75)\end{array}$ \\
\hline Ln(GDP Per Capita ${ }_{i t-1}^{2}$ ) & $\begin{array}{c}0.32 \\
(0.45)\end{array}$ & $\begin{array}{c}0.48 \\
(0.46)\end{array}$ & $\begin{array}{c}0.41 \\
(0.46)\end{array}$ & $\begin{array}{c}0.52 \\
(0.44)\end{array}$ & $\begin{array}{c}0.43 \\
(0.49)\end{array}$ & $\begin{array}{c}0.46 \\
(0.49)\end{array}$ \\
\hline Growth $_{i t-1}$ & $\begin{array}{c}0.02 \\
(0.02)\end{array}$ & $\begin{array}{c}0.02 \\
(0.02)\end{array}$ & $\begin{array}{c}0.02 \\
(0.02)\end{array}$ & $\begin{array}{c}0.03 \\
(0.03)\end{array}$ & $\begin{array}{c}0.02 \\
(0.02)\end{array}$ & $\begin{array}{c}0.02 \\
(0.02)\end{array}$ \\
\hline Ln(Government Spending $\left.{ }_{i t-1}\right)$ & $\begin{array}{c}-1.01 * \\
(0.42)\end{array}$ & $\begin{array}{c}-1.15^{*} \\
(0.49)\end{array}$ & $\begin{array}{c}-1.19 * \\
(0.47)\end{array}$ & $\begin{array}{c}-0.94^{*} \\
(0.41)\end{array}$ & $\begin{array}{c}-1.18^{*} \\
(0.48)\end{array}$ & $\begin{array}{c}-1.20 * \\
(0.50)\end{array}$ \\
\hline $\operatorname{Ln}\left(\right.$ Fossil Fuels $\left.{ }_{i t-1}\right)$ & $\begin{array}{c}-0.11 \\
(0.10)\end{array}$ & $\begin{array}{c}-0.09 \\
(0.13)\end{array}$ & $\begin{array}{c}-0.12 \\
(0.11)\end{array}$ & $\begin{array}{c}-0.17 \\
(0.09)\end{array}$ & $\begin{array}{c}-0.11 \\
(0.12)\end{array}$ & $\begin{array}{c}-0.12 \\
(0.12)\end{array}$ \\
\hline $\operatorname{Ln}\left(\right.$ Openness $\left.{ }_{i t-1}\right)$ & $\begin{array}{c}-1.31 \\
(0.70)\end{array}$ & $\begin{array}{c}-0.93 \\
(0.64)\end{array}$ & $\begin{array}{c}-0.83 \\
(0.66)\end{array}$ & $\begin{array}{c}-1.15 \\
(0.71)\end{array}$ & $\begin{array}{r}-0.83 \\
(0.71)\end{array}$ & $\begin{array}{r}-0.77 \\
(0.65)\end{array}$ \\
\hline Polity $_{i t-1}$ & $\begin{array}{c}-0.01 \\
(0.06)\end{array}$ & $\begin{array}{c}0.00 \\
(0.06)\end{array}$ & $\begin{array}{c}0.00 \\
(0.06)\end{array}$ & $\begin{array}{c}-0.04 \\
(0.06)\end{array}$ & $\begin{array}{c}-0.00 \\
(0.06)\end{array}$ & $\begin{array}{c}0.01 \\
(0.06)\end{array}$ \\
\hline $\operatorname{Ln}\left(\right.$ Other ODA Ot-1 $\left._{i}\right)$ & $\begin{array}{c}-0.04 \\
(0.12)\end{array}$ & $\begin{array}{c}-0.00 \\
(0.11)\end{array}$ & $\begin{array}{c}0.03 \\
(0.10)\end{array}$ & $\begin{array}{c}-0.06 \\
(0.08)\end{array}$ & $\begin{array}{c}-0.07 \\
(0.08)\end{array}$ & $\begin{array}{c}-0.03 \\
(0.09)\end{array}$ \\
\hline Ln(Climate Aid $\left._{i t-1}\right)$ & $\begin{array}{c}0.20 * \\
(0.08)\end{array}$ & $\begin{array}{c}0.21 * \\
(0.08)\end{array}$ & $\begin{array}{c}-0.17 \\
(0.17)\end{array}$ & $\begin{array}{c}-0.14 \\
(0.28)\end{array}$ & $\begin{array}{c}-0.19 \\
(0.59)\end{array}$ & $\begin{array}{c}-0.08 \\
(0.22)\end{array}$ \\
\hline Observations (Countries) & $531(50)$ & $635(53)$ & $635(53)$ & $509(50)$ & $578(50)$ & $598(50)$ \\
\hline$F($ Prob $>F)$ & $12.0(.000)$ & $20.4(.000)$ & $17.6(.000)$ & $14.8(.000)$ & $11.6(.000)$ & $19.7(.000)$ \\
\hline
\end{tabular}

Notes: Dependent variable: Adaptation Policy ${ }_{i t}$; Robust (country-clustered) standard errors in parentheses, * $p<.05$; All models include country and year fixed effects. 
COGITATIO

Table A2(a). Climate aid and change in Grantham climate policies.

\begin{tabular}{|c|c|c|c|c|c|c|}
\hline & \multicolumn{6}{|c|}{ Climate Aid Variable } \\
\hline & $\begin{array}{c}\text { All Climate } \\
\text { Commitments } \\
\text { (Rio) }\end{array}$ & $\begin{array}{c}\text { Mitigation } \\
\text { Commitments } \\
\text { (Michaelowa) }\end{array}$ & $\begin{array}{c}\text { Adaptation } \\
\text { Commitments } \\
\text { (Michaelowa) }\end{array}$ & $\begin{array}{c}\text { All Climate } \\
\text { Disbursements } \\
\text { (Rio) }\end{array}$ & $\begin{array}{c}\text { Mitigation } \\
\text { Disbursements } \\
\text { (Michaelowa) }\end{array}$ & $\begin{array}{c}\text { Adaptation } \\
\text { Disbursements } \\
\text { (Michaelowa) }\end{array}$ \\
\hline Ln(GDP Per Capita $)$ & $\begin{array}{c}1.21 \\
(1.20)\end{array}$ & $\begin{array}{c}1.07 \\
(0.95)\end{array}$ & $\begin{array}{c}1.09 \\
(0.96)\end{array}$ & $\begin{array}{c}2.34 \\
(1.22)\end{array}$ & $\begin{array}{c}2.46^{*} \\
(1.14)\end{array}$ & $\begin{array}{c}2.16 \\
(1.14)\end{array}$ \\
\hline Ln(GDP Per Capita $\left.{ }_{i}^{2}\right)$ & $\begin{array}{c}-0.08 \\
(0.08)\end{array}$ & $\begin{array}{c}-0.07 \\
(0.06)\end{array}$ & $\begin{array}{c}-0.07 \\
(0.06)\end{array}$ & $\begin{array}{c}-0.16 \\
(0.08)\end{array}$ & $\begin{array}{c}-0.17^{*} \\
(0.07)\end{array}$ & $\begin{array}{c}-0.15 \\
(0.07)\end{array}$ \\
\hline Growth $_{i}$ & $\begin{array}{c}0.04 \\
(0.03)\end{array}$ & $\begin{array}{c}0.03 \\
(0.03)\end{array}$ & $\begin{array}{c}0.03 \\
(0.03)\end{array}$ & $\begin{array}{c}0.03 \\
(0.03)\end{array}$ & $\begin{array}{c}0.03 \\
(0.03)\end{array}$ & $\begin{array}{c}0.03 \\
(0.03)\end{array}$ \\
\hline Ln(Government Spending $\left.{ }_{i}\right)$ & $\begin{array}{c}-0.21 \\
(0.31)\end{array}$ & $\begin{array}{c}-0.21 \\
(0.28)\end{array}$ & $\begin{array}{c}-0.22 \\
(0.28)\end{array}$ & $\begin{array}{c}-0.09 \\
(0.32)\end{array}$ & $\begin{array}{c}-0.02 \\
(0.31)\end{array}$ & $\begin{array}{c}-0.05 \\
(0.31)\end{array}$ \\
\hline Ln(Fossil Fuels ${ }_{i}$ ) & $\begin{array}{c}-0.01 \\
(0.06)\end{array}$ & $\begin{array}{c}0.01 \\
(0.06)\end{array}$ & $\begin{array}{c}0.01 \\
(0.06)\end{array}$ & $\begin{array}{c}-0.02 \\
(0.06)\end{array}$ & $\begin{array}{c}-0.02 \\
(0.07)\end{array}$ & $\begin{array}{c}-0.00 \\
(0.06)\end{array}$ \\
\hline Ln(Openness $\left.{ }_{i}\right)$ & $\begin{array}{c}-0.31 \\
(0.30) \\
\end{array}$ & $\begin{array}{c}-0.30 \\
(0.29) \\
\end{array}$ & $\begin{array}{c}-0.31 \\
(0.29) \\
\end{array}$ & $\begin{array}{c}-0.35 \\
(0.33) \\
\end{array}$ & $\begin{array}{c}-0.32 \\
(0.32) \\
\end{array}$ & $\begin{array}{c}-0.34 \\
(0.31) \\
\end{array}$ \\
\hline Polity $_{i}$ & $\begin{array}{l}0.06 * * \\
(0.02)\end{array}$ & $\begin{array}{l}0.06 * * \\
(0.02)\end{array}$ & $\begin{array}{c}0.06 * * \\
(0.02)\end{array}$ & $\begin{array}{c}0.06 * * \\
(0.02)\end{array}$ & $\begin{array}{c}0.06 * * \\
(0.02)\end{array}$ & $\begin{array}{c}0.06 * * \\
(0.02)\end{array}$ \\
\hline Ln(Other ODA $\left.{ }_{i}\right)$ & $\begin{array}{c}-0.18^{*} \\
(0.09)\end{array}$ & $\begin{array}{c}-0.20 * \\
(0.09)\end{array}$ & $\begin{array}{c}-0.18 \\
(0.11)\end{array}$ & $\begin{array}{c}-0.27 * \\
(0.11)\end{array}$ & $\begin{array}{c}-0.36^{* *} \\
(0.10)\end{array}$ & $\begin{array}{c}-0.28^{*} \\
(0.11)\end{array}$ \\
\hline Ln(Climate Commitments $\left.{ }_{i}\right)$ & $\begin{array}{c}-0.15 \\
(0.28)\end{array}$ & $\begin{array}{c}-0.12 \\
(0.26)\end{array}$ & $\begin{array}{c}-0.43 \\
(0.44)\end{array}$ & $\begin{array}{c}-0.97 \\
(1.16)\end{array}$ & $\begin{array}{c}-1.53 \\
(1.27)\end{array}$ & $\begin{array}{r}-1.58 \\
(0.83)\end{array}$ \\
\hline Constant & $\begin{array}{c}-0.32 \\
(4.83)\end{array}$ & $\begin{array}{c}0.10 \\
(3.97)\end{array}$ & $\begin{array}{c}0.15 \\
(3.95)\end{array}$ & $\begin{array}{c}-4.51 \\
(4.88)\end{array}$ & $\begin{array}{r}-5.10 \\
(4.55)\end{array}$ & $\begin{array}{r}-3.93 \\
(4.50)\end{array}$ \\
\hline Observations & 91 & 100 & 100 & 89 & 91 & 92 \\
\hline$F($ Prob $>F)$ & $3.60(.001)$ & $3.86(.000)$ & $4.50(.000)$ & $5.12(.000)$ & $5.95(.000)$ & $6.25(.000)$ \\
\hline
\end{tabular}

Notes: Dependent variable: Change in Climate Policy from 1995 to 2009; Robust standard errors in parentheses, $* * p<.01 * p<.05$. 
COGITATIO

Table A2(b). Climate aid and change in Grantham mitigation policies.

\begin{tabular}{|c|c|c|c|c|c|c|}
\hline & \multicolumn{6}{|c|}{ Climate Aid Variable } \\
\hline & $\begin{array}{l}\text { All Climate } \\
\text { Commitments } \\
\text { (Rio) }\end{array}$ & $\begin{array}{l}\text { Mitigation } \\
\text { Commitments } \\
\text { (Michaelowa) }\end{array}$ & $\begin{array}{l}\text { Adaptation } \\
\text { Commitments } \\
\text { (Michaelowa) }\end{array}$ & $\begin{array}{c}\text { All Climate } \\
\text { Disbursements } \\
\text { (Rio) }\end{array}$ & $\begin{array}{c}\text { Mitigation } \\
\text { Disbursements } \\
\text { (Michaelowa) }\end{array}$ & $\begin{array}{c}\text { Adaptation } \\
\text { Disbursements } \\
\text { (Michaelowa) }\end{array}$ \\
\hline Ln(GDP Per Capita $)$ & $\begin{array}{c}1.00 \\
(1.29)\end{array}$ & $\begin{array}{c}0.90 \\
(1.02)\end{array}$ & $\begin{array}{c}0.85 \\
(1.02)\end{array}$ & $\begin{array}{c}2.31 \\
(1.28)\end{array}$ & $\begin{array}{c}2.37^{*} \\
(1.16)\end{array}$ & $\begin{array}{c}2.01 \\
(1.18)\end{array}$ \\
\hline Ln(GDP Per Capita $\left.{ }_{i}^{2}\right)$ & $\begin{array}{c}-0.07 \\
(0.09)\end{array}$ & $\begin{array}{c}-0.06 \\
(0.07)\end{array}$ & $\begin{array}{c}-0.06 \\
(0.07)\end{array}$ & $\begin{array}{c}-0.16 \\
(0.08)\end{array}$ & $\begin{array}{c}-0.16^{*} \\
(0.08)\end{array}$ & $\begin{array}{c}-0.14 \\
(0.08)\end{array}$ \\
\hline Growth $_{i}$ & $\begin{array}{c}0.04 \\
(0.03)\end{array}$ & $\begin{array}{c}0.04 \\
(0.03)\end{array}$ & $\begin{array}{c}0.03 \\
(0.03)\end{array}$ & $\begin{array}{c}0.03 \\
(0.03)\end{array}$ & $\begin{array}{c}0.03 \\
(0.03)\end{array}$ & $\begin{array}{c}0.03 \\
(0.03)\end{array}$ \\
\hline Ln(Government Spending $\left.{ }_{i}\right)$ & $\begin{array}{c}-0.09 \\
(0.32)\end{array}$ & $\begin{array}{c}-0.11 \\
(0.28)\end{array}$ & $\begin{array}{c}-0.11 \\
(0.29)\end{array}$ & $\begin{array}{c}0.05 \\
(0.33)\end{array}$ & $\begin{array}{c}0.11 \\
(0.31)\end{array}$ & $\begin{array}{c}0.09 \\
(0.31)\end{array}$ \\
\hline Ln(Fossil Fuels $s_{i}$ & $\begin{array}{c}-0.01 \\
(0.06)\end{array}$ & $\begin{array}{c}0.01 \\
(0.06)\end{array}$ & $\begin{array}{c}0.01 \\
(0.06)\end{array}$ & $\begin{array}{c}-0.02 \\
(0.06)\end{array}$ & $\begin{array}{c}-0.02 \\
(0.07)\end{array}$ & $\begin{array}{c}-0.01 \\
(0.06)\end{array}$ \\
\hline Ln(Openness $\left.{ }_{i}\right)$ & $\begin{array}{c}-0.28 \\
(0.31)\end{array}$ & $\begin{array}{c}-0.28 \\
(0.29)\end{array}$ & $\begin{array}{c}-0.30 \\
(0.30)\end{array}$ & $\begin{array}{c}-0.34 \\
(0.34)\end{array}$ & $\begin{array}{c}-0.30 \\
(0.32)\end{array}$ & $\begin{array}{c}-0.32 \\
(0.31)\end{array}$ \\
\hline Polity $_{i}$ & $\begin{array}{c}0.06 * * \\
(0.02)\end{array}$ & $\begin{array}{c}0.06 * * \\
(0.02)\end{array}$ & $\begin{array}{c}0.06 * * \\
(0.02)\end{array}$ & $\begin{array}{c}0.06 * * \\
(0.02)\end{array}$ & $\begin{array}{c}0.06 * * \\
(0.02)\end{array}$ & $\begin{array}{c}0.06 * * \\
(0.02)\end{array}$ \\
\hline Ln(Other $\left.\mathrm{ODA}_{i}\right)$ & $\begin{array}{c}-0.21^{*} \\
(0.09)\end{array}$ & $\begin{array}{c}-0.22^{*} \\
(0.10)\end{array}$ & $\begin{array}{c}-0.20 \\
(0.11)\end{array}$ & $\begin{array}{c}-0.31^{* *} \\
(0.12)\end{array}$ & $\begin{array}{c}-0.40^{* *} \\
(0.10)\end{array}$ & $\begin{array}{c}-0.32^{* *} \\
(0.11)\end{array}$ \\
\hline Ln(Climate Commitments $\left.{ }_{i}\right)$ & $\begin{array}{c}-0.17 \\
(0.30)\end{array}$ & $\begin{array}{c}-0.21 \\
(0.28)\end{array}$ & $\begin{array}{c}-0.47 \\
(0.46)\end{array}$ & $\begin{array}{c}-1.00 \\
(1.19)\end{array}$ & $\begin{array}{c}-1.74 \\
(1.41)\end{array}$ & $\begin{array}{c}-1.84 \\
(0.98)\end{array}$ \\
\hline Constant & $\begin{array}{c}0.01 \\
(5.17)\end{array}$ & $\begin{array}{c}0.38 \\
(4.29)\end{array}$ & $\begin{array}{c}0.71 \\
(4.25)\end{array}$ & $\begin{array}{c}-4.79 \\
(5.19)\end{array}$ & $\begin{array}{c}-5.17 \\
(4.73)\end{array}$ & $\begin{array}{c}-3.82 \\
(4.73)\end{array}$ \\
\hline Observations & 91 & 100 & 100 & 89 & 91 & 92 \\
\hline$F($ Prob $>F)$ & $2.93(.004)$ & $3.05(.003)$ & $3.70(.001)$ & $4.72(.000)$ & $6.07(.000)$ & $6.05(.000)$ \\
\hline
\end{tabular}

Notes: Dependent variable: Change in Mitigation Policy from 1995 to 2009; Robust standard errors in parentheses, ${ }^{* *} p<.01 * p<.05$. 
COGITATIO

Table A2(c). Climate aid and change in Grantham adaptation policies.

\begin{tabular}{|c|c|c|c|c|c|c|}
\hline & \multicolumn{6}{|c|}{ Climate Aid Variable } \\
\hline & $\begin{array}{l}\text { All Climate } \\
\text { Commitments } \\
\text { (Rio) }\end{array}$ & $\begin{array}{c}\text { Mitigation } \\
\text { Commitments } \\
\text { (Michaelowa) }\end{array}$ & $\begin{array}{l}\text { Adaptation } \\
\text { Commitments } \\
\text { (Michaelowa) }\end{array}$ & $\begin{array}{c}\text { All Climate } \\
\text { Disbursements } \\
\text { (Rio) }\end{array}$ & $\begin{array}{c}\text { Mitigation } \\
\text { Disbursements } \\
\text { (Michaelowa) }\end{array}$ & $\begin{array}{l}\text { Adaptation } \\
\text { Disbursements } \\
\text { (Michaelowa) }\end{array}$ \\
\hline Ln(GDP Per Capita ${ }_{i}$ ) & $\begin{array}{c}2.61 \\
(1.83)\end{array}$ & $\begin{array}{c}2.23 \\
(1.57)\end{array}$ & $\begin{array}{c}2.68 \\
(1.58)\end{array}$ & $\begin{array}{c}2.63 \\
(1.79)\end{array}$ & $\begin{array}{c}3.18 \\
(1.87)\end{array}$ & $\begin{array}{c}3.17 \\
(1.80)\end{array}$ \\
\hline Ln(GDP Per Capita $\left.{ }_{i}^{2}\right)$ & $\begin{array}{c}-0.16 \\
(0.12)\end{array}$ & $\begin{array}{c}-0.14 \\
(0.10)\end{array}$ & $\begin{array}{c}-0.17 \\
(0.10)\end{array}$ & $\begin{array}{c}-0.16 \\
(0.11)\end{array}$ & $\begin{array}{c}-0.20 \\
(0.12)\end{array}$ & $\begin{array}{c}-0.20 \\
(0.11)\end{array}$ \\
\hline Growth $_{i}$ & $\begin{array}{c}0.03 \\
(0.06) \\
\end{array}$ & $\begin{array}{c}0.00 \\
(0.05) \\
\end{array}$ & $\begin{array}{c}0.02 \\
(0.05) \\
\end{array}$ & $\begin{array}{c}0.03 \\
(0.06) \\
\end{array}$ & $\begin{array}{c}0.03 \\
(0.06) \\
\end{array}$ & $\begin{array}{c}0.02 \\
(0.06) \\
\end{array}$ \\
\hline Ln(Government Spending $\left.{ }_{i}\right)$ & $\begin{array}{c}-0.90^{*} \\
(0.42) \\
\end{array}$ & $\begin{array}{c}-0.80^{*} \\
(0.39) \\
\end{array}$ & $\begin{array}{c}-0.82^{*} \\
(0.39) \\
\end{array}$ & $\begin{array}{c}-0.85^{*} \\
(0.42) \\
\end{array}$ & $\begin{array}{c}-0.78 \\
(0.42) \\
\end{array}$ & $\begin{array}{c}-0.83 \\
(0.43) \\
\end{array}$ \\
\hline Ln(Fossil Fuels $s_{i}$ ) & $\begin{array}{c}0.01 \\
(0.08) \\
\end{array}$ & $\begin{array}{c}0.02 \\
(0.08) \\
\end{array}$ & $\begin{array}{c}0.02 \\
(0.08) \\
\end{array}$ & $\begin{array}{c}0.01 \\
(0.08) \\
\end{array}$ & $\begin{array}{c}0.01 \\
(0.09) \\
\end{array}$ & $\begin{array}{c}0.02 \\
(0.08) \\
\end{array}$ \\
\hline $\operatorname{Ln}\left(\right.$ Openness $\left.{ }_{i}\right)$ & $\begin{array}{c}-0.51 \\
(0.40)\end{array}$ & $\begin{array}{c}-0.44 \\
(0.39) \\
\end{array}$ & $\begin{array}{c}-0.41 \\
(0.39) \\
\end{array}$ & $\begin{array}{c}-0.44 \\
(0.40)\end{array}$ & $\begin{array}{c}-0.43 \\
(0.41)\end{array}$ & $\begin{array}{c}-0.47 \\
(0.41) \\
\end{array}$ \\
\hline Polity $_{i}$ & $\begin{array}{c}0.06^{*} \\
(0.03) \\
\end{array}$ & $\begin{array}{c}0.06^{*} \\
(0.02) \\
\end{array}$ & $\begin{array}{c}0.06^{*} \\
(0.02) \\
\end{array}$ & $\begin{array}{c}0.06^{*} \\
(0.03) \\
\end{array}$ & $\begin{array}{c}0.06^{*} \\
(0.02) \\
\end{array}$ & $\begin{array}{c}0.05^{*} \\
(0.02) \\
\end{array}$ \\
\hline Ln(Other ODA ${ }_{i}$ ) & $\begin{array}{c}-0.04 \\
(0.17)\end{array}$ & $\begin{array}{c}-0.12 \\
(0.15)\end{array}$ & $\begin{array}{c}-0.05 \\
(0.18)\end{array}$ & $\begin{array}{c}-0.07 \\
(0.17)\end{array}$ & $\begin{array}{c}-0.15 \\
(0.17)\end{array}$ & $\begin{array}{c}-0.10 \\
(0.18)\end{array}$ \\
\hline Ln(Climate Commitments $\left.s_{i}\right)$ & $\begin{array}{c}-0.01 \\
(0.36)\end{array}$ & $\begin{array}{c}0.30 \\
(0.32) \\
\end{array}$ & $\begin{array}{c}-0.28 \\
(0.56)\end{array}$ & $\begin{array}{c}-0.90 \\
(1.42)\end{array}$ & $\begin{array}{c}-0.78 \\
(1.96)\end{array}$ & $\begin{array}{c}-0.83 \\
(0.93)\end{array}$ \\
\hline Constant & $\begin{array}{c}-6.05 \\
(6.84)\end{array}$ & $\begin{array}{c}-4.90 \\
(6.03) \\
\end{array}$ & $\begin{array}{c}-6.73 \\
(6.05) \\
\end{array}$ & $\begin{array}{c}-6.46 \\
(6.78) \\
\end{array}$ & $\begin{array}{c}-8.40 \\
(7.05)\end{array}$ & $\begin{array}{c}-8.17 \\
(6.83)\end{array}$ \\
\hline Observations & 91 & 100 & 100 & 89 & 91 & 92 \\
\hline $\mathrm{F}($ Prob $>\mathrm{F})$ & $2.78(.006)$ & $2.67(.008)$ & $2.92(.004)$ & $2.79(.006)$ & $2.70(.008)$ & $2.86(.005)$ \\
\hline
\end{tabular}

Notes: Dependent variable: Change in Adaptation Policy from 1995 to 2009; Robust standard errors in parentheses, ${ }^{*} p<.05$. 
COGITATIO

Table A3(a). Climate aid and Grantham climate policy, 4-year panels.

\begin{tabular}{|c|c|c|c|c|c|c|}
\hline & \multicolumn{6}{|c|}{ Climate Aid Variable } \\
\hline & $\begin{array}{c}\text { All Climate } \\
\text { Commitments } \\
\text { (Rio) }\end{array}$ & $\begin{array}{c}\text { Mitigation } \\
\text { Commitments } \\
\text { (Michaelowa) }\end{array}$ & $\begin{array}{c}\text { Adaptation } \\
\text { Commitments } \\
\text { (Michaelowa) }\end{array}$ & $\begin{array}{c}\text { All Climate } \\
\text { Disbursements } \\
\text { (Rio) }\end{array}$ & $\begin{array}{c}\text { Mitigation } \\
\text { Disbursements } \\
\text { (Michaelowa) }\end{array}$ & $\begin{array}{c}\text { Adaptation } \\
\text { Disbursements } \\
\text { (Michaelowa) }\end{array}$ \\
\hline Climate Policy $_{i t-1}$ & $\begin{array}{l}0.75^{* *} \\
(0.22)\end{array}$ & $\begin{array}{l}0.78 * * \\
(0.17)\end{array}$ & $\begin{array}{l}0.77^{* *} \\
(0.17)\end{array}$ & $\begin{array}{l}0.69 * * \\
(0.21)\end{array}$ & $\begin{array}{l}0.72 * * \\
(0.17)\end{array}$ & $\begin{array}{l}0.72 * * \\
(0.16)\end{array}$ \\
\hline Ln(GDP Per Capita $\left.{ }_{i t-1}\right)$ & $\begin{array}{c}-3.63 \\
(11.09)\end{array}$ & $\begin{array}{r}-5.81 \\
(9.50)\end{array}$ & $\begin{array}{c}-5.63 \\
(9.44)\end{array}$ & $\begin{array}{c}-4.70 \\
(11.51)\end{array}$ & $\begin{array}{c}-1.93 \\
(10.81)\end{array}$ & $\begin{array}{c}1.90 \\
(11.18)\end{array}$ \\
\hline Ln(GDP Per Capita $\left.{ }_{i t-1}^{2}\right)$ & $\begin{array}{c}0.29 \\
(0.73)\end{array}$ & $\begin{array}{c}0.47 \\
(0.59)\end{array}$ & $\begin{array}{c}0.45 \\
(0.58) \\
\end{array}$ & $\begin{array}{c}0.40 \\
(0.77)\end{array}$ & $\begin{array}{c}0.18 \\
(0.71)\end{array}$ & $\begin{array}{c}-0.05 \\
(0.74)\end{array}$ \\
\hline Growth $_{i t-1}$ & $\begin{array}{c}0.16 \\
(0.10)\end{array}$ & $\begin{array}{c}0.11 \\
(0.08)\end{array}$ & $\begin{array}{c}0.11 \\
(0.08) \\
\end{array}$ & $\begin{array}{c}0.10 \\
(0.10)\end{array}$ & $\begin{array}{c}0.09 \\
(0.10) \\
\end{array}$ & $\begin{array}{c}0.07 \\
(0.09) \\
\end{array}$ \\
\hline Ln(Government Spending $\left.{ }_{i t-1}\right)$ & $\begin{array}{c}0.16 \\
(1.66)\end{array}$ & $\begin{array}{c}0.06 \\
(1.51)\end{array}$ & $\begin{array}{c}0.15 \\
(1.50)\end{array}$ & $\begin{array}{c}0.58 \\
(1.49)\end{array}$ & $\begin{array}{c}0.34 \\
(1.49)\end{array}$ & $\begin{array}{c}0.21 \\
(1.47)\end{array}$ \\
\hline $\operatorname{Ln}\left(\right.$ Fossil Fuels $\left._{i t-1}\right)$ & $\begin{array}{c}-0.05 \\
(0.41) \\
\end{array}$ & $\begin{array}{c}-0.08 \\
(0.41) \\
\end{array}$ & $\begin{array}{c}-0.09 \\
(0.41)\end{array}$ & $\begin{array}{c}0.14 \\
(0.46) \\
\end{array}$ & $\begin{array}{c}0.09 \\
(0.46) \\
\end{array}$ & $\begin{array}{c}0.12 \\
(0.42) \\
\end{array}$ \\
\hline $\operatorname{Ln}\left(\right.$ Openness $\left.{ }_{i t-1}\right)$ & $\begin{array}{c}0.55 \\
(1.96) \\
\end{array}$ & $\begin{array}{c}0.41 \\
(1.89) \\
\end{array}$ & $\begin{array}{c}0.35 \\
(1.83) \\
\end{array}$ & $\begin{array}{c}0.05 \\
(1.85) \\
\end{array}$ & $\begin{array}{c}0.24 \\
(2.20) \\
\end{array}$ & $\begin{array}{c}0.20 \\
(2.05) \\
\end{array}$ \\
\hline Polity $_{i t-1}$ & $\begin{array}{c}0.08 \\
(0.08) \\
\end{array}$ & $\begin{array}{c}0.09 \\
(0.08) \\
\end{array}$ & $\begin{array}{c}0.08 \\
(0.08) \\
\end{array}$ & $\begin{array}{c}0.08 \\
(0.07) \\
\end{array}$ & $\begin{array}{c}0.08 \\
(0.08) \\
\end{array}$ & $\begin{array}{c}0.07 \\
(0.07) \\
\end{array}$ \\
\hline $\operatorname{Ln}\left(\right.$ Other ODA $\left.\mathrm{O}_{i t-1}\right)$ & $\begin{array}{c}-0.43 \\
(0.47) \\
\end{array}$ & $\begin{array}{c}-0.16 \\
(0.40) \\
\end{array}$ & $\begin{array}{c}-0.13 \\
(0.38) \\
\end{array}$ & $\begin{array}{c}-0.87 \\
(0.60) \\
\end{array}$ & $\begin{array}{c}-0.69 \\
(0.51) \\
\end{array}$ & $\begin{array}{c}-0.83 \\
(0.56)\end{array}$ \\
\hline $\operatorname{Ln}\left(\right.$ Climate Aid $\left._{i t-1}\right)$ & $\begin{array}{c}0.75 \\
(0.61) \\
\end{array}$ & $\begin{array}{c}-0.02 \\
(0.45)\end{array}$ & $\begin{array}{r}-0.90 \\
(0.65)\end{array}$ & $\begin{array}{c}0.21 \\
(1.24) \\
\end{array}$ & $\begin{array}{c}1.86 \\
(2.55) \\
\end{array}$ & $\begin{array}{c}1.80 \\
(2.13) \\
\end{array}$ \\
\hline Constant & $\begin{array}{c}12.32 \\
(42.42)\end{array}$ & $\begin{array}{c}18.26 \\
(38.91)\end{array}$ & $\begin{array}{c}17.79 \\
(38.73)\end{array}$ & $\begin{array}{c}14.91 \\
(43.90)\end{array}$ & $\begin{array}{c}6.34 \\
(41.27) \\
\end{array}$ & $\begin{array}{c}-8.38 \\
(42.02)\end{array}$ \\
\hline Observations (Countries) & $228(86)$ & $266(97)$ & $266(97)$ & $228(86)$ & $238(89)$ & $240(90)$ \\
\hline R-Squared & 0.67 & 0.70 & 0.70 & 0.69 & 0.69 & 0.70 \\
\hline
\end{tabular}


COGITATIO

Table A3(b). Climate aid and Grantham mitigation policy, 4-year panels.

\begin{tabular}{|c|c|c|c|c|c|c|}
\hline & \multicolumn{6}{|c|}{ Climate Aid Variable } \\
\hline & $\begin{array}{l}\text { All Climate } \\
\text { Commitments } \\
\text { (Rio) }\end{array}$ & $\begin{array}{c}\text { Mitigation } \\
\text { Commitments } \\
\text { (Michaelowa) }\end{array}$ & $\begin{array}{c}\text { Adaptation } \\
\text { Commitments } \\
\text { (Michaelowa) }\end{array}$ & $\begin{array}{c}\text { All Climate } \\
\text { Disbursements } \\
\text { (Rio) }\end{array}$ & $\begin{array}{c}\text { Mitigation } \\
\text { Disbursements } \\
\text { (Michaelowa) }\end{array}$ & $\begin{array}{c}\text { Adaptation } \\
\text { Disbursements } \\
\text { (Michaelowa) }\end{array}$ \\
\hline Climate Policy $_{i t-1}$ & $\begin{array}{l}0.78 * * \\
(0.25)\end{array}$ & $\begin{array}{l}0.79 * * \\
(0.18)\end{array}$ & $\begin{array}{c}0.78 * * \\
(0.18)\end{array}$ & $\begin{array}{l}0.71^{* *} \\
(0.24)\end{array}$ & $\begin{array}{c}0.72 * * \\
(0.18)\end{array}$ & $\begin{array}{l}0.72^{* *} \\
(0.17)\end{array}$ \\
\hline Ln(GDP Per Capita $\left.{ }_{i t-1}\right)$ & $\begin{array}{c}-0.63 \\
(9.76)\end{array}$ & $\begin{array}{c}-4.36 \\
(8.53)\end{array}$ & $\begin{array}{c}-4.37 \\
(8.51)\end{array}$ & $\begin{array}{c}-1.56 \\
(10.07)\end{array}$ & $\begin{array}{c}0.05 \\
(9.48)\end{array}$ & $\begin{array}{c}3.51 \\
(9.80) \\
\end{array}$ \\
\hline Ln(GDP Per Capita ${ }_{i t-1}^{2}$ ) & $\begin{array}{c}0.07 \\
(0.64)\end{array}$ & $\begin{array}{c}0.36 \\
(0.53)\end{array}$ & $\begin{array}{c}0.36 \\
(0.52)\end{array}$ & $\begin{array}{c}0.17 \\
(0.67)\end{array}$ & $\begin{array}{c}0.03 \\
(0.62)\end{array}$ & $\begin{array}{c}-0.18 \\
(0.65)\end{array}$ \\
\hline Growth $_{i t-1}$ & $\begin{array}{c}0.15 \\
(0.10)\end{array}$ & $\begin{array}{c}0.11 \\
(0.08)\end{array}$ & $\begin{array}{c}0.11 \\
(0.08)\end{array}$ & $\begin{array}{c}0.11 \\
(0.09)\end{array}$ & $\begin{array}{c}0.09 \\
(0.09)\end{array}$ & $\begin{array}{c}0.07 \\
(0.08)\end{array}$ \\
\hline Ln(Government Spending $\left.{ }_{i t-1}\right)$ & $\begin{array}{c}0.30 \\
(1.43) \\
\end{array}$ & $\begin{array}{c}0.23 \\
(1.27)\end{array}$ & $\begin{array}{c}0.31 \\
(1.26) \\
\end{array}$ & $\begin{array}{c}0.62 \\
(1.25)\end{array}$ & $\begin{array}{c}0.42 \\
(1.24)\end{array}$ & $\begin{array}{c}0.38 \\
(1.18)\end{array}$ \\
\hline $\operatorname{Ln}\left(\right.$ Fossil Fuels $\left.s_{i t-1}\right)$ & $\begin{array}{c}-0.04 \\
(0.37) \\
\end{array}$ & $\begin{array}{c}-0.07 \\
(0.37) \\
\end{array}$ & $\begin{array}{c}-0.07 \\
(0.37) \\
\end{array}$ & $\begin{array}{c}0.13 \\
(0.41) \\
\end{array}$ & $\begin{array}{c}0.10 \\
(0.42) \\
\end{array}$ & $\begin{array}{c}0.13 \\
(0.37) \\
\end{array}$ \\
\hline $\left.\operatorname{Ln}_{\left(O p e n n e s s_{i t-1}\right.}\right)$ & $\begin{array}{c}0.56 \\
(1.83)\end{array}$ & $\begin{array}{c}0.41 \\
(1.77)\end{array}$ & $\begin{array}{c}0.37 \\
(1.72)\end{array}$ & $\begin{array}{c}0.15 \\
(1.75)\end{array}$ & $\begin{array}{c}0.29 \\
(2.07)\end{array}$ & $\begin{array}{c}0.23 \\
(1.89)\end{array}$ \\
\hline Polity $_{i t-1}$ & $\begin{array}{c}0.06 \\
(0.06)\end{array}$ & $\begin{array}{c}0.07 \\
(0.06)\end{array}$ & $\begin{array}{c}0.07 \\
(0.06)\end{array}$ & $\begin{array}{c}0.06 \\
(0.05)\end{array}$ & $\begin{array}{c}0.06 \\
(0.06)\end{array}$ & $\begin{array}{c}0.05 \\
(0.05)\end{array}$ \\
\hline $\operatorname{Ln}\left(\right.$ Other ODA $\left.A_{i t-1}\right)$ & $\begin{array}{c}-0.33 \\
(0.39)\end{array}$ & $\begin{array}{c}-0.11 \\
(0.33)\end{array}$ & $\begin{array}{c}-0.08 \\
(0.32)\end{array}$ & $\begin{array}{c}-0.73 \\
(0.47)\end{array}$ & $\begin{array}{c}-0.63 \\
(0.41)\end{array}$ & $\begin{array}{c}-0.76 \\
(0.43)\end{array}$ \\
\hline $\operatorname{Ln}\left(\right.$ Climate Aid $\left._{i t-1}\right)$ & $\begin{array}{c}0.65 \\
(0.50)\end{array}$ & $\begin{array}{c}0.11 \\
(0.38)\end{array}$ & $\begin{array}{c}-0.63 \\
(0.56)\end{array}$ & $\begin{array}{c}0.21 \\
(1.19)\end{array}$ & $\begin{array}{c}2.55 \\
(2.09)\end{array}$ & $\begin{array}{c}1.62 \\
(1.78)\end{array}$ \\
\hline Constant & $\begin{array}{c}1.32 \\
(37.60)\end{array}$ & $\begin{array}{c}12.67 \\
(35.10)\end{array}$ & $\begin{array}{c}12.86 \\
(35.11)\end{array}$ & $\begin{array}{c}3.80 \\
(38.61)\end{array}$ & $\begin{array}{c}-0.70 \\
(36.25)\end{array}$ & $\begin{array}{c}-14.08 \\
(37.00)\end{array}$ \\
\hline Observations (Countries) & $228(86)$ & $266(97)$ & $266(97)$ & $228(86)$ & $238(89)$ & $240(90)$ \\
\hline R-Squared & 0.67 & 0.69 & 0.69 & 0.68 & 0.69 & 0.70 \\
\hline
\end{tabular}


COGITATIO

Table A3(c). Climate aid and Grantham adaptation policy, 4-year panels.

\begin{tabular}{|c|c|c|c|c|c|c|}
\hline & \multicolumn{6}{|c|}{ Climate Aid Variable } \\
\hline & $\begin{array}{l}\text { All Climate } \\
\text { Commitments } \\
\text { (Rio) }\end{array}$ & $\begin{array}{l}\text { Mitigation } \\
\text { Commitments } \\
\text { (Michaelowa) }\end{array}$ & $\begin{array}{l}\text { Adaptation } \\
\text { Commitments } \\
\text { (Michaelowa) }\end{array}$ & $\begin{array}{c}\text { All Climate } \\
\text { Disbursements } \\
\text { (Rio) }\end{array}$ & $\begin{array}{l}\text { Mitigation } \\
\text { Disbursements } \\
\text { (Michaelowa) }\end{array}$ & $\begin{array}{l}\text { Adaptation } \\
\text { Disbursements } \\
\text { (Michaelowa) }\end{array}$ \\
\hline Climate Policy $y_{i t-1}$ & $\begin{array}{c}0.39 * * \\
(0.14)\end{array}$ & $\begin{array}{c}0.47^{* *} \\
(0.13)\end{array}$ & $\begin{array}{c}0.47^{* *} \\
(0.13)\end{array}$ & $\begin{array}{c}0.43^{* *} \\
(0.15)\end{array}$ & $\begin{array}{c}0.49 * * \\
(0.16)\end{array}$ & $\begin{array}{c}0.45^{* *} \\
(0.16)\end{array}$ \\
\hline Ln(GDP Per Capita ${ }_{i t-1}$ ) & $\begin{array}{c}-2.74 \\
(2.12)\end{array}$ & $\begin{array}{c}-1.09 \\
(1.85)\end{array}$ & $\begin{array}{c}-0.93 \\
(1.85)\end{array}$ & $\begin{array}{c}-3.02 \\
(2.29)\end{array}$ & $\begin{array}{c}-1.86 \\
(2.16)\end{array}$ & $\begin{array}{c}-1.49 \\
(2.23)\end{array}$ \\
\hline Ln(GDP Per Capita ${ }_{i t-1}^{2}$ ) & $\begin{array}{c}0.22 \\
(0.14)\end{array}$ & $\begin{array}{c}0.10 \\
(0.11)\end{array}$ & $\begin{array}{c}0.09 \\
(0.11)\end{array}$ & $\begin{array}{c}0.24 \\
(0.15)\end{array}$ & $\begin{array}{c}0.15 \\
(0.14)\end{array}$ & $\begin{array}{c}0.13 \\
(0.15)\end{array}$ \\
\hline Growth $_{i t-1}$ & $\begin{array}{c}0.01 \\
(0.01)\end{array}$ & $\begin{array}{c}0.00 \\
(0.01)\end{array}$ & $\begin{array}{c}0.00 \\
(0.01)\end{array}$ & $\begin{array}{c}0.00 \\
(0.01)\end{array}$ & $\begin{array}{c}-0.00 \\
(0.01)\end{array}$ & $\begin{array}{c}-0.00 \\
(0.01)\end{array}$ \\
\hline Ln(Government Spending $\left.{ }_{i t-1}\right)$ & $\begin{array}{c}-0.06 \\
(0.31)\end{array}$ & $\begin{array}{c}-0.07 \\
(0.31)\end{array}$ & $\begin{array}{c}-0.04 \\
(0.31)\end{array}$ & $\begin{array}{c}0.03 \\
(0.33)\end{array}$ & $\begin{array}{c}-0.05 \\
(0.34)\end{array}$ & $\begin{array}{c}-0.07 \\
(0.34)\end{array}$ \\
\hline Ln(Fossil Fuels $\left.{ }_{i t-1}\right)$ & $\begin{array}{c}-0.04 \\
(0.06)\end{array}$ & $\begin{array}{c}-0.03 \\
(0.06)\end{array}$ & $\begin{array}{c}-0.04 \\
(0.06)\end{array}$ & $\begin{array}{c}-0.01 \\
(0.07)\end{array}$ & $\begin{array}{c}-0.02 \\
(0.07)\end{array}$ & $\begin{array}{c}-0.02 \\
(0.07)\end{array}$ \\
\hline Ln(Openness $\left.{ }_{i t-1}\right)$ & $\begin{array}{c}-0.05 \\
(0.14)\end{array}$ & $\begin{array}{c}-0.03 \\
(0.14)\end{array}$ & $\begin{array}{c}-0.05 \\
(0.13)\end{array}$ & $\begin{array}{c}-0.13 \\
(0.13)\end{array}$ & $\begin{array}{c}-0.07 \\
(0.16)\end{array}$ & $\begin{array}{c}-0.07 \\
(0.17)\end{array}$ \\
\hline Polity $_{i t-1}$ & $\begin{array}{c}0.02 \\
(0.03)\end{array}$ & $\begin{array}{c}0.03 \\
(0.03)\end{array}$ & $\begin{array}{c}0.02 \\
(0.03)\end{array}$ & $\begin{array}{c}0.02 \\
(0.03)\end{array}$ & $\begin{array}{c}0.02 \\
(0.03)\end{array}$ & $\begin{array}{c}0.02 \\
(0.03)\end{array}$ \\
\hline $\operatorname{Ln}\left(\right.$ Other ODA it-1 $\left._{1}\right)$ & $\begin{array}{c}-0.11 \\
(0.10)\end{array}$ & $\begin{array}{c}-0.05 \\
(0.08)\end{array}$ & $\begin{array}{c}-0.06 \\
(0.08)\end{array}$ & $\begin{array}{c}-0.14 \\
(0.14)\end{array}$ & $\begin{array}{c}-0.06 \\
(0.12)\end{array}$ & $\begin{array}{c}-0.08 \\
(0.13)\end{array}$ \\
\hline Ln(Climate Aid $\left._{i t-1}\right)$ & $\begin{array}{c}0.17 \\
(0.15)\end{array}$ & $\begin{array}{c}-0.11 \\
(0.12)\end{array}$ & $\begin{array}{c}-0.27 \\
(0.15)\end{array}$ & $\begin{array}{c}0.02 \\
(0.26)\end{array}$ & $\begin{array}{c}-0.47 \\
(0.74)\end{array}$ & $\begin{array}{c}0.10 \\
(0.53)\end{array}$ \\
\hline Constant & $\begin{array}{c}9.45 \\
(8.03)\end{array}$ & $\begin{array}{c}3.63 \\
(7.69)\end{array}$ & $\begin{array}{c}3.05 \\
(7.75)\end{array}$ & $\begin{array}{l}10.09 \\
(8.85)\end{array}$ & $\begin{array}{c}6.13 \\
(8.59)\end{array}$ & $\begin{array}{c}4.63 \\
(8.76)\end{array}$ \\
\hline Observations (Countries) & $228(86)$ & $266(97)$ & $266(97)$ & $228(86)$ & $238(89)$ & $240(90)$ \\
\hline R-Squared & 0.51 & 0.50 & 0.51 & 0.51 & 0.49 & 0.50 \\
\hline
\end{tabular}


COGITATIO

Table A4(a). Climate aid and CLIMI (aid averaged over 2000-2005).

\begin{tabular}{|c|c|c|c|c|c|c|}
\hline & \multicolumn{6}{|c|}{ Climate Aid Variable } \\
\hline & $\begin{array}{c}\text { All Climate } \\
\text { Commitments } \\
\text { (Rio) }\end{array}$ & $\begin{array}{c}\text { Mitigation } \\
\text { Commitments } \\
\text { (Michaelowa) }\end{array}$ & $\begin{array}{c}\text { Adaptation } \\
\text { Commitments } \\
\text { (Michaelowa) }\end{array}$ & $\begin{array}{c}\text { All Climate } \\
\text { Disbursements } \\
\text { (Rio) }\end{array}$ & $\begin{array}{c}\text { Mitigation } \\
\text { Disbursements } \\
\text { (Michaelowa) }\end{array}$ & $\begin{array}{c}\text { Adaptation } \\
\text { Disbursements } \\
\text { (Michaelowa) }\end{array}$ \\
\hline Ln(GDP Per Capita $\left.{ }_{i}\right)$ & $\begin{array}{c}0.38 \\
(0.36)\end{array}$ & $\begin{array}{c}0.18 \\
(0.32)\end{array}$ & $\begin{array}{c}0.20 \\
(0.29)\end{array}$ & $\begin{array}{c}0.63^{*} \\
(0.31)\end{array}$ & $\begin{array}{c}0.54 \\
(0.36)\end{array}$ & $\begin{array}{c}0.53 \\
(0.32)\end{array}$ \\
\hline Ln(GDP Per Capita ${ }_{i}^{2}$ ) & $\begin{array}{c}-0.02 \\
(0.02)\end{array}$ & $\begin{array}{c}-0.01 \\
(0.02)\end{array}$ & $\begin{array}{c}-0.01 \\
(0.02)\end{array}$ & $\begin{array}{c}-0.04 \\
(0.02)\end{array}$ & $\begin{array}{c}-0.03 \\
(0.02)\end{array}$ & $\begin{array}{c}-0.03 \\
(0.02)\end{array}$ \\
\hline Growth $_{i}$ & $\begin{array}{c}0.01 \\
(0.01)\end{array}$ & $\begin{array}{c}0.01 \\
(0.01)\end{array}$ & $\begin{array}{c}0.01 \\
(0.01)\end{array}$ & $\begin{array}{c}0.00 \\
(0.01)\end{array}$ & $\begin{array}{c}0.00 \\
(0.01)\end{array}$ & $\begin{array}{c}0.00 \\
(0.01)\end{array}$ \\
\hline Ln(Government Spending $\left.{ }_{i}\right)$ & $\begin{array}{r}-0.04 \\
(0.10)\end{array}$ & $\begin{array}{c}-0.04 \\
(0.10)\end{array}$ & $\begin{array}{c}-0.03 \\
(0.09)\end{array}$ & $\begin{array}{c}-0.01 \\
(0.08)\end{array}$ & $\begin{array}{c}-0.03 \\
(0.08)\end{array}$ & $\begin{array}{c}-0.03 \\
(0.08)\end{array}$ \\
\hline Ln(Fossil Fuels ${ }_{i}$ ) & $\begin{array}{r}-0.00 \\
(0.01)\end{array}$ & $\begin{array}{c}0.00 \\
(0.02)\end{array}$ & $\begin{array}{c}0.00 \\
(0.01)\end{array}$ & $\begin{array}{c}-0.01 \\
(0.01)\end{array}$ & $\begin{array}{c}-0.00 \\
(0.02)\end{array}$ & $\begin{array}{c}-0.01 \\
(0.01)\end{array}$ \\
\hline Ln(Openness $\left.s_{i}\right)$ & $\begin{array}{c}-0.04 \\
(0.06)\end{array}$ & $\begin{array}{c}-0.00 \\
(0.05)\end{array}$ & $\begin{array}{c}0.00 \\
(0.05)\end{array}$ & $\begin{array}{c}-0.02 \\
(0.06)\end{array}$ & $\begin{array}{c}-0.01 \\
(0.06)\end{array}$ & $\begin{array}{c}-0.01 \\
(0.06)\end{array}$ \\
\hline Polity $_{i}$ & $\begin{array}{c}0.01 * \\
(0.00)\end{array}$ & $\begin{array}{l}0.02 * * \\
(0.00)\end{array}$ & $\begin{array}{l}0.02 * * \\
(0.00)\end{array}$ & $\begin{array}{c}0.01^{* *} \\
(0.00)\end{array}$ & $\begin{array}{c}0.01 * * \\
(0.00)\end{array}$ & $\begin{array}{c}0.01^{* *} \\
(0.00)\end{array}$ \\
\hline Ln(Other ODA O $_{i}$ & $\begin{array}{c}-0.05 \\
(0.04)\end{array}$ & $\begin{array}{c}-0.05 \\
(0.04)\end{array}$ & $\begin{array}{c}-0.05 \\
(0.04)\end{array}$ & $\begin{array}{c}-0.08^{*} \\
(0.03)\end{array}$ & $\begin{array}{c}-0.07^{*} \\
(0.03)\end{array}$ & $\begin{array}{c}-0.07^{*} \\
(0.03)\end{array}$ \\
\hline Ln(Climate Commitments $\left.s_{i}\right)$ & $\begin{array}{c}0.05 \\
(0.11)\end{array}$ & $\begin{array}{c}0.01 \\
(0.08)\end{array}$ & $\begin{array}{c}-0.04 \\
(0.18)\end{array}$ & $\begin{array}{c}-0.34 \\
(0.39)\end{array}$ & $\begin{array}{c}-0.37 \\
(0.31)\end{array}$ & $\begin{array}{c}-0.02 \\
(0.17)\end{array}$ \\
\hline Constant & $\begin{array}{c}-1.03 \\
(1.34)\end{array}$ & $\begin{array}{c}-0.46 \\
(1.29)\end{array}$ & $\begin{array}{c}-0.58 \\
(1.21)\end{array}$ & $\begin{array}{c}-2.04 \\
(1.11)\end{array}$ & $\begin{array}{r}-1.66 \\
(1.36)\end{array}$ & $\begin{array}{r}-1.66 \\
(1.16)\end{array}$ \\
\hline Observations & 46 & 55 & 55 & 46 & 47 & 48 \\
\hline R-squared & 0.43 & 0.48 & 0.48 & 0.50 & 0.43 & 0.42 \\
\hline
\end{tabular}

Notes: Dependent variable: CLIMli; Robust standard errors in parentheses, ${ }^{* *} p<.01 * p<.05$. 
COGITATIO

Table A4(b). Climate aid and CLIMI (aid averaged over 2005-2010).

\begin{tabular}{|c|c|c|c|c|c|c|}
\hline & \multicolumn{6}{|c|}{ Climate Aid Variable } \\
\hline & $\begin{array}{c}\text { All Climate } \\
\text { Commitments } \\
\text { (Rio) }\end{array}$ & $\begin{array}{c}\text { Mitigation } \\
\text { Commitments } \\
\text { (Michaelowa) }\end{array}$ & $\begin{array}{l}\text { Adaptation } \\
\text { Commitments } \\
\text { (Michaelowa) }\end{array}$ & $\begin{array}{c}\text { All Climate } \\
\text { Disbursements } \\
\text { (Rio) }\end{array}$ & $\begin{array}{c}\text { Mitigation } \\
\text { Disbursements } \\
\text { (Michaelowa) }\end{array}$ & $\begin{array}{c}\text { Adaptation } \\
\text { Disbursements } \\
\text { (Michaelowa) }\end{array}$ \\
\hline Ln(GDP Per Capita $\left.{ }_{i}\right)$ & $\begin{array}{c}0.45 \\
(0.49)\end{array}$ & $\begin{array}{c}0.44 \\
(0.47)\end{array}$ & $\begin{array}{c}0.42 \\
(0.47)\end{array}$ & $\begin{array}{l}1.02 * * \\
(0.34)\end{array}$ & $\begin{array}{l}1.01^{* *} \\
(0.35)\end{array}$ & $\begin{array}{l}1.01^{* *} \\
(0.32)\end{array}$ \\
\hline Ln(GDP Per Capita $\left.{ }_{i}^{2}\right)$ & $\begin{array}{r}-0.03 \\
(0.03)\end{array}$ & $\begin{array}{c}-0.03 \\
(0.03)\end{array}$ & $\begin{array}{c}-0.02 \\
(0.03)\end{array}$ & $\begin{array}{c}-0.06^{* *} \\
(0.02)\end{array}$ & $\begin{array}{c}-0.06^{* *} \\
(0.02)\end{array}$ & $\begin{array}{c}-0.06^{* *} \\
(0.02)\end{array}$ \\
\hline Growth $_{i}$ & $\begin{array}{c}0.00 \\
(0.01)\end{array}$ & $\begin{array}{c}0.00 \\
(0.01)\end{array}$ & $\begin{array}{c}0.00 \\
(0.01)\end{array}$ & $\begin{array}{c}-0.00 \\
(0.01)\end{array}$ & $\begin{array}{r}-0.00 \\
(0.01)\end{array}$ & $\begin{array}{r}-0.00 \\
(0.01)\end{array}$ \\
\hline Ln(Government Spending ${ }_{i}$ ) & $\begin{array}{c}-0.05 \\
(0.11)\end{array}$ & $\begin{array}{c}-0.04 \\
(0.11)\end{array}$ & $\begin{array}{c}-0.04 \\
(0.11)\end{array}$ & $\begin{array}{c}0.04 \\
(0.12)\end{array}$ & $\begin{array}{c}0.03 \\
(0.11)\end{array}$ & $\begin{array}{c}0.03 \\
(0.11)\end{array}$ \\
\hline Ln(Fossil Fuels ${ }_{i}$ ) & $\begin{array}{c}0.00 \\
(0.02)\end{array}$ & $\begin{array}{c}0.00 \\
(0.02)\end{array}$ & $\begin{array}{c}0.00 \\
(0.02)\end{array}$ & $\begin{array}{c}-0.01 \\
(0.01)\end{array}$ & $\begin{array}{c}-0.01 \\
(0.01)\end{array}$ & $\begin{array}{c}-0.01 \\
(0.01)\end{array}$ \\
\hline Ln(Openness $\left.s_{i}\right)$ & $\begin{array}{c}0.01 \\
(0.09)\end{array}$ & $\begin{array}{c}0.01 \\
(0.09)\end{array}$ & $\begin{array}{c}0.02 \\
(0.09)\end{array}$ & $\begin{array}{c}-0.04 \\
(0.07)\end{array}$ & $\begin{array}{c}-0.03 \\
(0.07)\end{array}$ & $\begin{array}{c}-0.03 \\
(0.07)\end{array}$ \\
\hline Polity $_{i}$ & $\begin{array}{c}0.01 * \\
(0.00)\end{array}$ & $\begin{array}{c}0.01 * \\
(0.00)\end{array}$ & $\begin{array}{c}0.01 * \\
(0.00)\end{array}$ & $\begin{array}{l}0.01 * * \\
(0.00)\end{array}$ & $\begin{array}{l}0.01 * * \\
(0.00)\end{array}$ & $\begin{array}{l}0.01^{* *} \\
(0.00)\end{array}$ \\
\hline Ln(Other ODA $\left.{ }_{i}\right)$ & $\begin{array}{c}-0.04 \\
(0.04)\end{array}$ & $\begin{array}{c}-0.05 \\
(0.04)\end{array}$ & $\begin{array}{c}-0.03 \\
(0.03)\end{array}$ & $\begin{array}{c}-0.08 * * \\
(0.02)\end{array}$ & $\begin{array}{c}-0.08 * * \\
(0.02)\end{array}$ & $\begin{array}{c}-0.06 * * \\
(0.02)\end{array}$ \\
\hline Ln(Climate Commitments $\left.s_{i}\right)$ & $\begin{array}{r}-0.00 \\
(0.05)\end{array}$ & $\begin{array}{c}0.02 \\
(0.06)\end{array}$ & $\begin{array}{c}-0.09 \\
(0.10)\end{array}$ & $\begin{array}{c}0.05 \\
(0.12)\end{array}$ & $\begin{array}{c}0.16 \\
(0.24)\end{array}$ & $\begin{array}{c}-0.13 \\
(0.11)\end{array}$ \\
\hline Constant & $\begin{array}{r}-1.49 \\
(1.73)\end{array}$ & $\begin{array}{c}-1.48 \\
(1.65)\end{array}$ & $\begin{array}{c}-1.47 \\
(1.67)\end{array}$ & $\begin{array}{c}-3.54^{* *} \\
(1.27)\end{array}$ & $\begin{array}{c}-3.51^{*} \\
(1.32)\end{array}$ & $\begin{array}{c}-3.53^{* *} \\
(1.18)\end{array}$ \\
\hline Observations & 46 & 46 & 46 & 44 & 44 & 44 \\
\hline R-squared & 0.35 & 0.35 & 0.37 & 0.57 & 0.57 & 0.58 \\
\hline
\end{tabular}

Notes: Dependent variable: CLIMli; Robust standard errors in parentheses, $* * p<.01 * p<.05$. 